Published in final edited form as:

Cancer Metastasis Rev. 2011 December ; 30(0): 277-294. doi:10.1007/s10555-011-9310-3.

\title{
Cyclooxygenases and lipoxygenases in cancer
}

\author{
Claus Schneider and \\ Department of Pharmacology, Vanderbilt University Medical School, Nashville, TN 37232, USA \\ Vanderbilt Institute of Chemical Biology, Vanderbilt University Medical School, Nashville, TN \\ 37232, USA
}

\author{
Ambra Pozzi \\ Department of Medicine, Vanderbilt University Medical School, Nashville, TN 37232, USA \\ Department of Cancer Biology, Vanderbilt University Medical School, Nashville, TN 37232, USA \\ Veterans Affairs Hospitals, Nashville, TN 37215, USA \\ Departments of Medicine and Cancer Biology, Division of Nephrology and Hypertension, \\ Vanderbilt University, Medical Center North, B3115, Nashville, TN 37232, USA \\ ambra.pozzi@vanderbilt.edu
}

\begin{abstract}
Cancer initiation and progression are multistep events that require cell proliferation, migration, extravasation to the blood or lymphatic vessels, arrest to the metastatic site, and ultimately secondary growth. Tumor cell functions at both primary or secondary sites are controlled by many different factors, including growth factors and their receptors, chemokines, nuclear receptors, cellcell interactions, cell-matrix interactions, as well as oxygenated metabolites of arachidonic acid. The observation that cyclooxygenases and lipoxygenases and their arachidonic acid-derived eicosanoid products (prostanoids and HETEs) are expressed and produced by tumor cells, together with the finding that these enzymes can regulate cell growth, survival, migration, and invasion, has prompted investigators to analyze the roles of these enzymes in cancer progression. In this review, we focus on the contribution of cyclooxygenase- and lipoxygenase-derived eicosanoids to tumor cell function in vitro and in vivo and discuss hope and tribulations of targeting these enzymes for cancer prevention and treatment.
\end{abstract}

\section{Keywords}

Cancer; Eicosanoids; Thromboxane; Prostacyclin; Prostaglandins; Inhibitors

\section{Introduction}

In order to grow and metastasize, tumor cells release autocrine and paracrine signals that can affect tumor cells themselves as well and the host microenvironment. In addition, the tumor cells receive constant cues from the surrounding microenvironment, comprised of tumorassociated fibroblasts, immune cells, and endothelial cells. This host-tumor interaction is key in regulating processes such as tumor cell proliferation, migration, extravasation, and ultimately metastatic growth. These events are regulated by many different factors, including growth factors and their receptors, cytokines, cell-cell and cell-matrix

(C) Springer Science+Business Media, LLC 2011

Correspondence to: Ambra Pozzi. 
interactions, as well as lipid products. Among these lipids, arachidonic acidderived products are the most studied in the context of tumor development and growth [1]. Three major enzymatic pathways are used for the oxidative transformation of arachidonic acid into the cellular signaling hormones that are collectively termed eicosanoids. Lipoxygenases (LOX) add molecular oxygen to the fatty acid to form the hydro(pero)xyeicosatetraenoic acids; cyclooxygenases (COX) perform a double oxygenation reaction to yield the prostaglandin endoperoxide prostaglandin $\mathrm{H}_{2}\left(\mathrm{PGH}_{2}\right)$ as the common precursor molecule to all prostaglandins (including prostacyclin and thromboxane); and finally, the cytochrome P450 monooxygenases perform an epoxidation or $\omega / \omega-1$ hydroxylation of arachidonic acid (Fig. 1). The observation that COX, LOX, and P450 monooxygenases are upregulated in either tumor cells or surrounding microenvironment, and that these enzymes control processes such as cell proliferation, migration, and survival, prompted investigators to analyze the effects of these enzymes in tumorigenesis. In this review, we focus on the role of tumor-as well as hostprovided COX- and LOX-derived eicosanoids in tumorigenesis and describe how they can either promote or inhibit tumor cell function both in vivo and in vitro. We will also describe an example of the crossover of the 5-LOX and COX-2 biosynthetic pathways with formation of a novel di-endoperoxide analogous to $\mathrm{PGH}_{2}$ and highlight strengths and pitfalls related to the use of COX and/or LOX inhibitors for the treatment of cancer.

\section{COX-derived products in tumorigenesis}

Until the late 1980s, only one isoform of COX had been identified (now recognized as COX-1). In 1990s, an inducible COX isoform was identified and called COX-2. Whereas COX-1 is constitutively expressed in most tissues, COX-2 is an immediate-early gene which is induced by cytokines, mitogens, growth factors, and carcinogens. COX-1 and COX-2 catalyze the rate-limiting steps in the biosynthesis of prostaglandins and thromboxane from arachidonic acid. Both COX enzymes convert arachidonic acid to $\mathrm{PGH}_{2}$ and downstream selective isomerases convert $\mathrm{PGH}_{2}$ to prostacyclin, prostaglandins $\mathrm{D}_{2}, \mathrm{E}_{2}$, or $\mathrm{F}_{2 \mathrm{a}}$, or thromboxane $\mathrm{A}_{2}$ (Fig. 1). The finding that COX-2 expression increases in mouse models of adenomas, in human colorectal cancer, followed by the observation that COX-2 also plays a role in colorectal metastasis [2-4] and tumor-associated angiogenesis [5, 6], has initiated a line of research devoted to the identification of COX-2-derived products responsible for initiation and promotion of cancer. These studies have become more intense after the finding that COX-2 is also overexpressed in many other tumor types, such as hepatocarcinoma, lung cancer, breast cancer, and more recently melanoma, supporting the notion that COX-2, the inducible isoform of cyclooxygenase, plays a crucial role in oncogenesis [7]. Genetic and pharmacological inhibition of COX-2 has resulted in decreased incidence of primary and metastatic tumor growth, clearly identifying COX-2 as an ideal target for anti-tumorigenic therapy. In this context, deletion of the COX-2 gene or chemical inhibition suppresses adenoma development in APC ${ }^{\Delta 716}$ mice and Min mice $[8,9]$ and results in significantly reduced UV-induced tumorigenesis [10]. Silencing of COX-2 inhibits metastasis and delays tumor onset of poorly differentiated metastatic breast cancer cells [11]. Likewise, pharmacological inhibition of COX-2 has shown promising results in halting tumor growth and progression [12]. Although most of the pro-tumorigenic activity of COX-2 is attributed to the generation of prostaglandin $\mathrm{E}_{2}\left(\mathrm{PGE}_{2}\right)$, it is important to highlight that the other COX-2-derived products can also affect tumor development. We will therefore describe the role of the five major prostanoids thromboxane $\left(\mathrm{TxA}_{2}\right)$, prostacyclin $\left(\mathrm{PGI}_{2}\right)$, prostaglandin $\mathrm{D}_{2}\left(\mathrm{PGD}_{2}\right)$, prostaglandin $\mathrm{F}_{2 \mathrm{a}}\left(\mathrm{PGF}_{2 \mathrm{a}}\right)$, and $\mathrm{PGE}_{2}$ in tumorigenesis.

\subsection{Thromboxane}

The highly unstable $\mathrm{TxA}_{2}$ is formed from $\mathrm{PGH}_{2}$ via thromboxane synthase (TXAS) (Fig. 1). Besides the rearrangement into TxA 2 , TXAS also catalyzes the cleavage of $\mathrm{PGH}_{2}$ into malondialdehyde (MDA) and the 17 carbon hydroxy fatty acid, HHT (12S-hydroxy-5Z,8E, 
10E-heptadecatrienoic acid), such that the three products are formed in a 1:1:1 ratio [13]. It is not well established to what extent the products MDA and HHT contribute to the role of TXAS in tumorigenesis. TxA $A_{2}$ can affect cell function via interaction with the two thromboxane receptors TPalpha and TPbeta, leading to the induction of diverse physiological/pathophysiological responses, including platelet aggregation and smooth muscle contraction. $\mathrm{TxA}_{2}$ has been shown to be involved in allergies, modulation of acquired immunity and atherogenesis [14]. In addition, $\mathrm{TxA}_{2}$ has been shown to play a role in angiogenesis and tumorigenesis. A pro-tumorigenic role for $\mathrm{TxA}_{2}$ and its receptors comes from the observation that TXAS overexpression has been reported in a range of cancers and is associated with poor prognosis. Increased expression of TXAS is evident in patients with non-small cell lung cancer, particularly in the adenocarcinoma subtype [15]. In addition, the smoke-related carcinogen 4-(methylnitrosamino)-1-(3-pyridyl)-1-butanone promotes cell survival and growth of human lung cancer cells via stimulation of TXAS, consistent with the increased levels of this enzyme in lung cancer tissues of smokers [16]. Consistent with this data, selective inhibition of TXAS leads to lung cancer cell apoptosis by preventing cAMP response element binding (CREB) activity [17] as well as stimulating reactive oxygen species production and reduction of nuclear factor-kappaB (NF-KB) activation [18]. Although the upregulation of the TPbeta receptor has been reported in lung cancer cells upon exposure to carcinogen [15], the TPalpha receptor seems to transduce the $\mathrm{TxA}_{2}$ mediated pro-tumorigenic activity in lung cancer cells. In this context, the activation of TPalpha receptor leads to increased expression of vascular endothelial growth factor (VEGF) and subsequent angiogenesis [19], upregulation of COX-2 [20], as well as upregulation of Nurr1, and orphan receptor that has been shown to stimulate proliferation [21].

In addition to lung cancer, $\mathrm{TxA}_{2}$ seems to play a protumorigenic role also in gliobastoma, as inhibition of TXAS improves glioblastoma response to chemotherapy and radiation [22, 23]. Thus, TxA 2 contributes to tumorigenesis (Fig. 2) and maneuvers aimed to inhibit either its production (i.e., thromboxane synthase) or target (i.e., TPalpha and TPbeta receptors) can be viewed as a potential anti-tumorigenic therapy.

\subsection{Prostacyclin}

$\mathrm{PGI}_{2}$ is derived from $\mathrm{PGH}_{2}$ via prostacyclin synthase (Fig. 1) and it can exert its functions via activation of a single prostacyclin receptor, $I P$. PGI $_{2}$ is primarily produced by endothelial cells, and similar to thromboxane, it can regulate many different events, including vasodilation, inhibition of platelet aggregation, leukocyte adhesion, and inflammation. However, in contrast to thromboxane, $\mathrm{PGI}_{2}$ is thought to be an anti-tumorigenic eicosanoid $[24,25]$. This hypothesis is supported by the observation that prostacyclin synthase overexpression is chemopreventive in a murine model of chemical and cigarette smokeinduced lung cancer [26, 27]. Moreover, hypermethylation of the prostacyclin synthase promoter, associated with diminished gene expression, is a recurrent alteration in colorectal carcinogenesis [28], and treatment with the stable $\mathrm{PGI}_{2}$ analog Iloprost slows the progression of lung cancer in a patient with systemic sclerosis [29]. One possible mechanism whereby $\mathrm{PGI}_{2}$ is anti-tumorigenic is by preventing clot formation and subsequent binding and survival of tumor cells to aggregated platelets [30]. By preventing platelet aggregation, $\mathrm{PGI}_{2}$ might also reduce the amount of plateletsecreted VEGF and unwanted angiogenesis [31]. In addition to these platelet-mediated effects, it has been recently shown that $\mathrm{PGI}_{2}$ can prevent non-small cell lung cancer growth by enhancing frizzled-9 expression and activation of the peroxisome proliferator-activated receptor (PPAR)gamma [32, 33]. Interestingly, this novel $\mathrm{PGI}_{2} /$ frizzled-9 crosstalk does not correlate with the expression of the cell surface receptor for $\mathrm{PGI}_{2}$, suggesting that $\mathrm{PGI}_{2}$ might exert an anti-tumorigenic activity in a receptor-independent manner. These data seem to agree with 
the finding that in vivo overexpression of prostacyclin synthase equally protects wild type and prostacyclin receptor-null mice from carcinogeninduced lung tumor incidence [33]. Thus, $\mathrm{PGI}_{2}$ protects from tumor development (Fig. 2) in a receptor-independent manner, and maneuvers aimed to enhance its synthesis (i.e., prostacyclin synthase) or action (i.e., $\mathrm{PGI}_{2}$ analogs) can be viewed as a potential anti-tumorigenic therapy.

\subsection{Prostaglandin $\mathrm{D}_{2}$}

$\mathrm{PGD}_{2}$ is derived from $\mathrm{PGH}_{2}$ (Fig. 1) via two distinct prostaglandin D synthases (PGDS), namely hematopoietic and lipocalin-type (L-PGDS) synthases, and it can exert its functions via activation of two distinct $\mathrm{PGD}_{2}$ receptors that are named DP (or DP1) and CRTH2 (or DP2) [34-36]. $\mathrm{PGD}_{2}$ is a major inflammatory mediator implicated in asthma and allergic rhinitis. It is largely produced as the major COX metabolite upon allergen-provoked degranulation of mast cells. Interestingly, in recent years, a role for $\mathrm{PGD}_{2}$ as antitumorigenic lipid has been proposed. This statement is supported by the observation that the expression of L-PGDS is significantly downregulated in human lung cancer and its levels inversely correlate to malignancy [37]. In addition, in vitro overexpression of L-PGDS inhibits non-small cell lung cancer proliferation [37] and renders melanoma cells more susceptible to retinoic acidmediated apoptosis [38]. More evidence that $\mathrm{PGD}_{2}$ has an antitumorigenic potential comes from the finding that this COX-2-derived product can promote apoptosis via activation of the caspase-dependent pathway in human colorectal cancer and lung cancer cells $[39,40]$. $\mathrm{PGD}_{2}$ also upregulates the expression of the transcription factor SOX9 in melanoma cells, thus making these cells more sensitive to treatment with retinoic acid [41]. Whether these antitumorigenic effects are DP and/or CRTH2 dependent is at present unclear, as blocking these receptors with the selective antagonists BWA868C and ramatroban does not seem to prevent $\mathrm{PGD}_{2}$-mediated apoptosis in vitro [40]. A convincing role of DP receptor in mediating $\mathrm{PGD}_{2}$ antitumorigenic activity comes from the demonstration that mice lacking the DP receptor have enhanced tumor progression accompanied by increased tumor-associated angiogenesis [42]. Most importantly, in vivo treatment with the DP agonist BW245C inhibits tumor growth in a DP-dependent manner, clearly emphasizing a protective role of the $\mathrm{PGD}_{2} / \mathrm{DP}$ axis in tumorigenesis [42].

$\mathrm{PGD}_{2}$ can undergo dehydration/isomerization reactions to form the cyclopentenone prostaglandin 15 -deoxy- $\Delta^{12,14}-\mathrm{PGJ}_{2}\left(15 \mathrm{~d}-\mathrm{PGJ} \mathrm{J}_{2}\right)$. Since $15 \mathrm{~d}-\mathrm{PGJ}_{2}$ is considered an endogenous PPARgamma ligand [43], and activation of PPARgamma has been shown to have anti-tumorigenic activity [44], the role of $\mathrm{PGJ}_{2}$ metabolites in modulation of tumor cell function has been investigated. Similarly to $\mathrm{PGD}_{2}, 15 \mathrm{~d}-\mathrm{PGJ}_{2}$ decreases migration and invasion of breast cancer cells [45], promotes colon cancer apoptosis [46], decreases the expression of the anti-apoptotic Bcl-2 in human hepatocellular carcinoma cells [47], and induces mitotic arrest by destabilizing microtubules [48]. Finally, the activation of PPARgamma by $15 \mathrm{~d}-\mathrm{PGJ}_{2}$ reduces the transcription of the pro-tumorigenic thromboxane TPbeta receptor in erythroleukemial cells [49]. The electrophilic character of the two ketoene moieties of $15 \mathrm{~d}-\mathrm{PGJ}_{2}$ is the mechanistic basis for the covalent inhibition of IKB kinase, a major regulator of the transcription factor NF-KB [50]. The inhibition of IKB kinase could be a mechanism of the anti-tumorigenic activity of $15 \mathrm{~d}-\mathrm{PGJ}_{2}$ due to the crucial role of NF$\mathrm{KB}$ in regulating cell survival in malignant cells [51]. In conclusion, $\mathrm{PGD}_{2}$ and its metabolite $15 \mathrm{~d}-\mathrm{PGJ}_{2}$ can exert anti-tumorigenic action (Fig. 2) via binding to the DP receptor, by activating the anti-tumorigenic nuclear receptor PPARgamma, or by inhibition of NF-KB.

\subsection{Prostaglandin $F_{2 \alpha}$}

$\mathrm{PGF}_{2 \mathrm{a}}$ is derived from $\mathrm{PGH}_{2}$ via prostaglandin $\mathrm{F}$ synthase (Fig. 1) and it can exert its function via binding to the $\mathrm{FP}$ receptor. A potential contribution of the $\mathrm{PGF}_{2 \mathrm{a}} / \mathrm{FP}$ receptor axis in tumorigenesis has been widely analyzed in endometrial cancers. Analysis of human 
samples of endometrial cancers showed that the expression of the FP receptor and its ligand $\mathrm{PGF}_{2 \mathrm{a}}$ are increased compared to normal tissue, and this increase correlates to poor prognosis [52]. $\mathrm{PGF}_{2 \alpha}$ might contribute to tumorigenesis by promoting the synthesis of both pro-tumorigenic and pro-angiogenic genes, including COX-2, VEGF, and b-FGF [53-55]. In addition, in vitro studies indicate that the FP receptor can modulate the adhesive properties of tumor cells by affecting actin reorganization and consequent motility [56], while $\mathrm{PGF}_{2 \alpha}$ upregulates chemokines important to control of cell proliferation $[57,58]$. In addition to its direct effect on tumor cells, $\mathrm{PGF}_{2 \mathrm{a}}$ might contribute to tumorigenesis by stimulating the synthesis of the neutrophil chemo attractant CXCL1, thus modulating the inflammatory microenvironment [59]. Thus, $\mathrm{PGF}_{2 \alpha}$ exerts pro-tumorigenic activity (Fig. 2) and blocking $\mathrm{PGF}_{2 \mathrm{a}} / \mathrm{FP}$ receptor interaction might be viewed as a valid tool to block and prevent cancer progression.

\subsection{Prostaglandin $\mathrm{E}_{2}$}

$\mathrm{PGE}_{2}$ is generated from $\mathrm{PGH}_{2}$ via prostaglandin $\mathrm{E}$ synthase (Fig. 1). $\mathrm{PGE}_{2}$ is the most widely produced prostanoid in the body [60] and it exerts its cellular effects by binding to four distinct E-prostanoid receptors (EP1-4) [61]. The finding that mice lacking $\mathrm{PGE}_{2}$ synthases are protected from carcinogen-induced colon cancer [62], together with the observation that downregulation of this synthase in human prostate and lung cancer reduces their clonogenic capacity and in vivo growth [63], clearly support a role for $\mathrm{PGE}_{2}$ as a protumorigenic lipid.

$\mathrm{PGE}_{2}$ binds four distinct EP receptors that have different and often opposing biological effects [64]. For example, although the EP2 and EP4 receptors upregulate intracellular cAMP levels, they exert different downstream effects on important intracellular mediators, including the phosphatidylinositol 3-kinases (PI3K) and extracellular signalregulated kinase (ERK) pathways [65, 66]. Moreover, the EP3 receptor usually counteracts EP2- and EP4mediated upregulation of cAMP by preferentially coupling to $G_{i}$ proteins [61] or by controlling the small GTPase RhoA function by coupling to Ga12 [67]. Thus, the development of mice lacking or overexpressing EP receptors has been very valuable in analyzing the involvement of selective $\mathrm{PGE}_{2} / \mathrm{EP}$ signaling in tumorigenesis.

The role of EP1 in tumorigenesis is at present controversial. A pro-tumorigenic role of EP1 has been established by generating mice that overexpress this $\mathrm{PGE}_{2}$ receptor selectively in the skin. Despite reduced tumor multiplicity following DMBA/TPA regime, these mice show higher papilloma to carcinoma conversion rate [68], suggesting that EP1 plays a positive role in tumor progression. In vitro studies show that EP1 promotes $\mathrm{PGE}_{2}$-enhanced migration of oral cancer cells [69] as well chondrosarcoma cells [70] by regulating the expression of intracellular and matrix adhesion molecules. In contrast to this data, a protective role for EP1 in breast cancer progression has been postulated based on the finding that pharmacologic antagonism of EP1 or receptor silencing by shRNA increases breast cancer cell metastatic capacity [71]. These studies, together with the finding that survival of women with tumors negative for EP1 is significantly worse than that of women with EP1 expression [71], suggest the hypothesis that EP1 functions as a metastasis suppressor gene. Finally, global loss of EP1 receptor does not seem to affect the early growth of tumorbearing EP1-null and wild-type mice [72]. Thus, EP1 might contribute to or protect from tumor formation/promotion (Fig. 2) and these effects seem to be dependent on the animal model and the nature of the tumor.

In contrast to EP1, the EP2 receptor has been reported to play a pro-tumorigenic role. EP2null mice produce significantly fewer tumors than wild-type mice in a two-stage skin carcinogenesis protocol [73] and show significantly decreased growth and pulmonary metastasis following injection of breast cancer cells [74]. These findings, together with the 
observation that EP2 is overexpressed in esophageal squamous cell carcinoma [75] and its overexpression positively correlates to tumor invasion, clearly suggest that EP2 contributes to tumor growth and progression (Fig. 2) and maneuvers to inhibit $\mathrm{PGE}_{2} / \mathrm{EP} 2$ signaling might be beneficial. In this regard, treatment of mice with a soluble EP2 receptor, thus competing for $\mathrm{PGE}_{2}$ binding with the endogenous receptor, has been shown to suppress the growth of endometrial cancer [76], further supporting the idea that EP-targeting strategy might be used for the treatment of cancer.

Similarly to EP2, the EP3 receptor seems to play a protumorigenic action. The use of EP3null mice has allowed to identify a positive role for this receptor in tumor-associated lymphangiogenesis [77], as well as in regulating the expression of VEGF and matrix metalloproteinase thus promoting tumor-associated angiogenesis and tumor metastasis [78, 79]. Whereas EP3 seems to play a positive role in tumor-associated vasculature, and its loss is overall beneficial, there is also evidence that this receptor might work as a tumor suppressor gene. This hypothesis is supported by the observation that EP3 expression is decreased in colon cancer in mice, rats, and humans when compared with normal mucosa [80], and re-expression of EP3 receptor in cancer cells reduced their growth both in vivo and in vitro [67]. All together these data seem to indicate EP3 exerts both pro- and antitumorigenic function (Fig. 2), and these effects are dependent on whether this receptor affects tumor- or host-mediated responses.

The contribution of the EP4 receptor to tumorigenesis is more difficult to evaluate given that $-80 \%$ of the EP4-null mice die at birth due to ductus arterious [81]. In vitro studies indicate that EP4 mediates colon carcinoma cell growth via ERK activation [66, 82] and confers resistance to spontaneous apoptosis and promotes anchorage-independent growth [83]. Studies with human non-small cell lung cancer indicate that EP4 activation confers an invasive phenotype via Src activation [84]. In vivo evidence that the EP4 receptor is protumorigenic comes from the finding that treatment of mice with EP4 antagonists reduces the metastatic potential of lung and colon cancer cells [85]. Moreover, EP4 plays a key role in supporting the progression of androgen-resistant prostate cancer cells both in vitro and in vivo [86]. In addition to its direct role on tumor cells, EP4 might exert pro-tumorigenic action by regulating endothelial cell function. Studies of primary endothelial cells derived from EP4 ${ }^{\text {flox/flox }}$ mice [87] revealed that this receptor directly controls endothelial cell migration and tubulogenesis in vitro, and that activation of the EP4 receptor by selective agonists promotes angiogenesis in vivo [88]. Thus, EP4 receptor exerts protumorigenic functions (Fig. 2) and antagonizing its signaling might be viewed as a valid tool for cancer treatment.

\section{LOX-derived products in tumorigenesis}

LOXs are categorized according to their positional specificity of arachidonic acid oxygenation into 5-, 8-, 12-, and 15-LOX [89]. LOXs oxygenate arachidonic acid to hydroperoxyeicosatetraenoic acids (HPETEs) that are subsequently reduced to corresponding hydroxyeicosatetraenoic acids (HETEs). 5-, 8-, 12- and 15-HETE are therefore the major arachidonic acid metabolites formed by mammalian LOXs [89]. The 15LOX-1 isozyme can also efficiently metabolize linoleic acid leading to the formation of 13hydroxyoctadecadienoic acid (13-HODE) [90]. In the case of the 5-LOX enzyme, the primary 5-HPETE product is further metabolized by the same enzyme to form the unstable leukotriene $\mathrm{A}_{4}\left(\mathrm{LTA}_{4}\right)$ epoxide, the precursor of the cysteinyl leukotrienes $\left(\mathrm{LTC}_{4}, \mathrm{LTD}_{4}\right.$, and $\left.\mathrm{LTE}_{4}\right)$ and leukotriene $\mathrm{B}_{4}\left(\mathrm{LTB}_{4}\right)$. Alternatively, 5-HPETE undergoes reduction to 5HETE, a prominent product of 5-LOX catalysis in leukocytes. Lipoxins are a group of eicosanoids formed by consecutive oxygenation of arachidonic acid by two LOX enzymes, one of which is usually 5-LOX. In lipoxin biosynthesis, 15-HETE (or 12-HETE) derived 
from 15-LOX (or 12-LOX) is transformed by 5-LOX catalyzing an LT-type transformation to yield lipoxins $\mathrm{A}_{4}$ and $\mathrm{B}_{4}$ [91]. Figure 1 summarizes the major LOX-derived metabolites. The most studied LOXs are the 5-LOX from leukocytes, the platelet-type 12-LOX, and the reticulocyte-type 12/15-LOX (15-LOX-1). However, the interest in this family of enzymes has increased after the finding that LOX isoforms can also be found in tumor, stromal, or immune cells, thus strongly suggest a role for these enzymes in tumor development and growth [89].

\subsection{5-LOX}

Histological analysis of human adenoma samples suggests a strong correlation of 5-LOX expression with increased polyp size, intraepithelial neoplasia and adenoma, indicating that this enzyme might play a role in early stages of colon cancer [92]. Consistent with this finding, inhibition of 5-LOX with Rev5901 prevents colon cancer cell proliferation both in vitro and in vivo [93]. Increased 5-LOX activity has been also associated with carcinogenesis in human oral cavity tissues [94] and treatment with the herbal preparation zyflamend significantly reduces hyperplasia and dysplasia in a mouse model of oral squamous cell carcinoma [95]. Interestingly, the beneficial effects of zyflamend are accompanied by significant decreased levels of $\mathrm{LTB}_{4}$, a metabolite of 5-LOX. Finally, 5LOX is becoming a promising target for nonsolid tumors, such as chronic myeloid leukemia. In this context, Chen and colleagues have recently shown that the expression of 5-LOX by leukemia stem cells is critical for BCR-ABL-induced chronic myeloid leukemia. 5-LOX deficiency or selective inhibition causes leukemia stem cells failure to differentiate, divide, and survive thus preventing chronic myeloid leukemia development [96].

5-LOX might contribute to carcinogenesis directly by controlling tumor cell function and/or indirectly by affecting the surrounding microenvironment (Fig. 3). Inhibiting or suppressing 5-LOX expression in tumor cells is necessary to promote growth arrest and apoptosis, as well as block epithelial mesenchymal transition in various tumor cell lines [97-99].

Moreover, both 5-HETE and $\mathrm{LTB}_{4}$ are known to recruit and activate inflammatory cells as well as increase vascular permeability, two key steps in tumorigenesis [100, 101].

\subsection{8-LOX}

8-LOX is the murine homologue to the human 15-LOX-2 isozyme (see below for details). The role of this murine LOX in tumorigenesis is at present not well defined. Overexpression of 8-LOX in premalignant keratinocytes leads to inhibition of cell growth linked to inhibition of DNA synthesis [102], and mice overexpressing 8-LOX selectively in the epidermis show highly differentiated keratinocytes [103]. In contrast to these data, the expression of 8-LOX is highly upregulated in mouse model of skin carcinogenesis [104]. However, whether the upregulation of 8-LOX is beneficial to counteract cancer development or is deleterious and contributes to cancer progression is unknown (Fig. 3).

\subsection{2-LOX}

In the mid-1990s, the finding that 12-LOX is expressed in murine lung carcinoma cells [105], followed by the evidence that 12-LOX expression correlates with advanced stages of prostate cancer in humans [106], has initiated studies aimed to determine if and how this enzyme contributes to tumorigenesis [89]. Evidence that 12-LOX might contribute to tumorigenesis comes from the finding that 12 -LOX expression was elevated in prostate cancer tissue compared with their corresponding normal tissues. Consequently, urinary levels of 12-HETE have been reported to be significantly elevated in prostate cancer patients [107]. Another evidence that 12-LOX contributes to tumor cell proliferation and survival is demonstrated by the finding that 12-LOX-specific antisense oligonucleotides or treatment with the 12-LOX inhibitor baicalein induces tumor cell apoptosis by regulating the levels of 
Bcl-2 [108-110]. In addition to Bcl-2, 12-LOX might affect cell survival by controlling the arrest at the G1/S-phase, inhibiting kinases such as Akt and mitogen-activated protein kinases (MAPKs), and affecting the expression of inflammatory transcription factors such as NF-KB [89].

Besides its direct role on tumor cells, 12-LOX could act as a pro-tumorigenic gene by affecting tumor-associated angiogenesis. In this regard, 12-LOX-transfected cells form bigger and more vascularized tumors than vector-transfected cells [111], suggesting a proangiogenic function of 12-LOX products. $12 S$-HETE promotes endothelial cell proliferation and migration [112,113] by stimulating VEGF neo-synthesis [114], by promoting endothelial cell retraction in a PKC-dependent manner [115], and by increasing the surface expression of integrin av $\beta 3$ [116], a receptor expressed primarily in angiogenic blood vessels [117]. Although it is clear that 12-LOX might act as an oncogene (Fig. 3), is not entirely clear how LOX products exerts such functions. Studies from the Hammarström laboratory suggest that 12-HETE might control cell function by interacting with a receptor complex with both a cytosolic and nuclear localization [118-122], although the selective receptor on tumor cells has not been identified yet.

\subsection{5-LOX}

Two 15 LOX isoforms, namely 15-LOX-1 and 15-LOX-2, have been described. Whereas 15-LOX-1 can generate 13-HODE from linoleic acid (see below for details), 15-LOX-2 shows preference for oxygenation of arachidonic acid forming 15-HETE. Whether 15LOX-2/15-HETE signaling plays a protective and/or deleterious effect in tumorigenesis is controversial [123]. The expression of 15-LOX-2 is downregulated in breast cancer and colorectal adenomas $[124,125]$ and patients with advanced epithelial ovarian cancer show decreased levels of 15-HETE in tumor peritoneum [126]. Studies on prostate cancer indicate that 15-LOX-2 is anti-tumorigenic and acts as tumor suppressor by inhibiting cell cycle progression [127, 128] or promoting cell senescence [129]. Consistent with this data, 15LOX-2 is highly expressed in normal prostate, while its expression is decreased in prostate cancer $[127,130]$. In contrast to a protective role of 15 -LOX-2 in cancer, mice overexpressing 15-LOX-2 selectively in the prostate show age-dependent prostatic hyperplasia and enlargement of the prostate [131]. The overexpression of 15-LOX-2 in the prostate is accompanied by increased expression of stem cell progenitor markers and overall increased cell proliferation [131]. However, hyperplasia does not progress to carcinoma due to increased ratio of senescent cells. All together, these results indicate that although 15LOX-2 expression might lead to prostate cancer initiation, it might prevent prostate cancer progression. Thus, 15-LOX-2 can be viewed as a proand anti-metastatic gene (Fig. 3), thus making it an ambiguous target for cancer therapy.

\subsection{HODEs}

13-HODE, a 15-LOX-1-derived linoleic acid metabolite, is an endogenous ligand and activator of PPARgamma. 13-HODE can also activate PPARgamma indirectly by downregulating the expression and activity of PPARdelta [132, 133]. PPARgamma acts as an anti-tumorigenic receptor as its activation by endogenous and exogenous ligands inhibits tumor cell proliferation and growth as well as induces differentiation and apoptosis [44, 134]. Based on this finding, the possible role of the 15-LOX-1/13-HODE axis as a negative regulator of tumor growth/development has been investigated. Significant reductions in the levels of 13-HODE are observed in human lung cancer tissue, as well as in animal models of lung cancer. Decreased tumor levels of 13-HODE parallel decreased activity of PPARgamma, suggesting a protective role for the PPARgamma/13-HODE in lung cancer development [135]. Consistent with an anti-tumorigenic activity of 13-HODE, treatment of human colon carcinoma cells with 13-HODE decreases cell proliferation, and 
overexpression of 15-LOX-1 in the same cells reduces their tumorigenic activity in vivo [136]. Finally, white tea extract promotes human non-small cell lung cancer cell apoptosis by increasing PPARgamma activation and mRNA expression, with concomitant increases in 15-LOX-1 expression [137]. To further corroborate a protective role of 15-LOX-1 in tumorigenesis, mice overexpressing 15-LOX-1 specifically in the endothelium show reduced angiogenesis and tumor formation [138] most likely due to downregulation of VEGF, PLGF, and VEGFR2 expression [139]. In contrast to a protective role of 15-LOX-1 in cancer, it has been shown that 13-HODE promotes the growth of hepatoma cells in vivo and in vitro, and treatment with the pan-LOX inhibitor nordihydroguaiaretic acid is beneficial in reducing circulating levels of 13-HODE and consequent tumor growth [140]. Finally, although 15-LOX-1 expression is downregulated in colorectal adenomas [125], increased levels of the same enzyme are evident in human prostate cancer [141] and the use of the mouse TRAMP model has allowed to establish a direct correlation between 15LOX-1 expression, 13-HODE synthesis, and prostate cancer progression [142]. Thus, the 15-LOX-1/13-HODE axis can promote or inhibit tumorigenesis (Fig. 3) and these effects seem to be tumor selective, thus making this axis another ambiguous target for antitumorigenic therapy.

\subsection{Lipoxins}

Lipoxins have been initially described as endogenous anti-inflammatory molecules and have been primarily studied in many inflammation-related disease models [143, 144]. As inflammation plays a direct role in cancer development, a new role for lipoxins as negative regulators of tumorigenesis has been proposed. Exogenous administration of $\mathrm{LXA}_{4}$ has been shown to decrease the in vivo growth of hepatocarinoma $\mathrm{H} 22$ cells by inhibiting secretion of VEGF by tumor cells and consequent angiogenesis [145]. Consistent with the idea that lipoxins exert anti-angiogenic functions, $\mathrm{LXA}_{4}$ prevents nuclear HIF-1alpha translocation under hypoxic conditions in endothelial cells. This results in decreased VEGF expression and consequent decreased tubulogenic activity and cell migration [146]. In addition to inhibiting the production of pro-angiogenic factors, lipoxins might inhibit endothelial cell migration by preventing VEGF-mediated formation of focal adhesion and stress fibers [147]. Finally, lipoxins can prevent VEGF-mediated activation of PI3K and ERK, two kinases involved in endothelial cell proliferation [148]. Thus, lipoxins are antiinflammatory, anti-tumorigenic, and anti-angiogenic mediators (Fig. 3) and maneuvers to enhance their synthesis could be viewed as a potential tool for cancer treatment.

\section{Convergence of the 5-LOX and COX-2 pathway: new pro-tumorigenic lipids?}

In 2006, in vitro biochemical studies suggested a new role for the 5-LOX product $5 S$-HETE [149]. In this new role, $5 S$-HETE serves as a substrate for COX-2 forming a bicyclic diendoperoxide with structural similarities to the arachidonic acid-derived prostaglandin endoperoxide $\mathrm{PGH}_{2}$. The reaction with $5 S$-HETE is specific for COX-2 (COX-1 does not react with $5 S$-HETE), and only $5 S$-HETE can serve as substrate for formation of a diendoperoxide, but not 5R-HETE or any of the other HETE isomers [149]. More recently, it has been shown that the unstable di-endoperoxide can undergo nonenzymatic rearrangement to form two cyclic hemiketal (HK) eicosanoids, namely $\mathrm{HKD}_{2}$ and $\mathrm{HKE}_{2}$ [150]. Both $\mathrm{HKD}_{2}$ and $\mathrm{HKE}_{2}$ are endogenously generated upon activation of human peripheral blood leukocytes with calcium ionophore A23187 and LPS in order to stimulate 5-LOX activity in neutrophils or eosinophils and COX-2 expression in monocytes, respectively [150]. Furthermore, $\mathrm{HKD}_{2}$ and $\mathrm{HKE}_{2}$ stimulate migration and tubulogenesis of microvascular endothelial cells, implicating a pro-angiogenic role of these novel eicosanoids [150]. Although it is premature to speculate whether the hemiketal eicosanoids might play a role in 
tumorigenesis, it is plausible that biosynthesis of hemiketals could take place in a tumor infiltrated by neutrophils (as a source of 5-HETE) and activated macrophages (providing COX-2). The hemiketals could then contribute to tumor growth by stimulating endothelial cell migration and tubulogenesis and subsequent angiogenesis. This possible scenario is illustrated in Fig. 4.

\section{Single versus dual inhibition of COX and LOX in tumorigenesis}

Given that most COX-2- and/or LOX-generated lipids seem to play a positive role in tumorigenesis (Figs. 2 and 3), inhibition of these two major enzymes of arachidonic acid metabolism might be viewed as a valid tool to prevent cancer formation. However, as these enzymes can also generate anti-tumorigenic lipids (Figs. 2 and 3) and control physiological functions such as inflammation and blood pressure, the use of COX and LOX inhibitory drugs has both advantages and disadvantages that are highlighted below.

\subsection{LOX inhibitors as anti-tumorigenic agents}

As mentioned above, the observations that (a) 5-LOX and 12-LOX expression and activity are upregulated in certain tumor types [89], (b) the levels of 12-HETE correlate with progression of various cancers [151], and (c) 5-LOX can produce leukotrienes that exert pro-inflammatory action and increase microvascular permeability, make these LOXs a potential target for anti-tumorigenic therapy. Studies on human prostate cells indicate that overexpression of 12-LOX results in a significant increase in pro-angiogenic factors [114] and treatment with a pan inhibitor of LOX (nordihydroguaiaretic acid) or with a 12-LOX inhibitor (baicalein) prevents their synthesis [114]. In murine prostate cells, treatment with baicalein directly prevents cell proliferation in vitro and tumorigenesis in vivo, confirming the anti-tumorigenic effects of baicalein administration. In human breast cancer and nonsmall cell lung cancer cells, specific inhibition of 12-LOX resulted in significant cell apoptosis via regulation of caspase pathways [152], while 12-LOX inhibition induces apoptosis of A431 by promoting caspase-3 activation and inhibiting ERK and P13K activation [153]. All together these data strongly indicate that 12-LOX can be viewed as a pro-angiogenic and pro-tumorigenic enzyme and its inhibition can provide a valid tool for anti-tumorigenic therapy.

In addition to 12-LOX, the inhibition of 5-LOX could also be beneficial as it might inhibit tumor growth/development by decreasing inflammation and, at the same time, directly affecting tumor cell function. In the past few years, effort has been made in generating and refining 5-LOX inhibitors for the treatment of inflammation, allergies, cardiovascular disease, and cancer [154]. Recently, a new generation of 5-LOX inhibitors has been described and shown to selectively inhibit 5-LOX activity in vitro as well as to decrease the incidence of adenoma in APCmin/+ mice [155]. In addition, novel di-O-prenylated chalcone derivatives have been generated and shown to be potent 5-LOX inhibitors in vivo and to inhibit human breast cancer cell proliferation in vitro [156]. Finally, MK591, a selective 5LOX inhibitor with promising potential as anti-asthma drug, has been shown to induce human prostate cancer cell apoptosis, thus making this inhibitor a promising anticancer drug [157]. Despite these very promising results, it has been recently shown that some 5-LOX inhibitors might lead to cytotoxic and anti-proliferative effects independently of suppression of 5-LOX activity. Thus, selective versus nonselective effects of certain inhibitors need to be carefully evaluated to avoid unwanted side effects, including targeting and killing of normal cells [158].

LOX-targeted anti-tumorigenic therapy is more complicated when 15-LOX becomes the target. As mentioned above, both 15-LOX-1 and 15-LOX-2 have been shown to play both pro- and anti-tumorigenic action. Overexpression of 15-LOX-1 in Du145 prostate cancer 
cells prevents their growth in vivo, while overexpression of the same isoforms in PC-3 prostate cells enhances their growth in vivo [89]. Similarly, studies performed on endothelial cells suggest that this isoform can have both pro- and anti-angiogenic activities (see above for details), clearly indicating the difficulty of targeting the 15-LOX isozymes for antitumorigenic activity.

A major complicating factor for defining the role of LOXs in cancer or, for that matter, in any other disease or in normal physiology is that potent- and isoform-specific inhibitors of the different LOX isozymes are not available, except in the case of 5-LOX. Thus, the use of phenolic-and/or redox-active compounds as putative LOX inhibitors (i.e., nordihydroguaiaretic acid and baicalein) bears the possibility that unrelated enzymatic reactions are affected or that the observed affects are caused directly by the inhibitor.

\subsection{COX inhibitors as anti-tumorigenic agents}

Epidemiological studies on regular use of nonsteroidal antiinflammatory drugs (NSAIDs) have provided an early link of prostaglandin formation and the risk of developing colon cancer. A large population-based observational study also demonstrated that low-dose aspirin reduces the relative risk of fatal colon cancer [159], and chronic ingestion of NSAIDs significantly reduces colon polyp formation and recurrence [160, 161]. Increased levels of COX-2, the target of NSAIDs, have been observed in various types of tumors including colon, lung, and breast cancer and its overexpression is associated with poor outcome [162]. Despite the promising results with COX-2 inhibition, a few years ago the US Food and Drug Administration issued a warning concerning the cardiovascular side effects of NSAIDs and COX selective inhibitors [163] as they lead to an increased prothrombotic risk, raise blood pressure, and heart failure [164]. Unfortunately, the ability of the COX-2 selective inhibitors to reduce pro-tumorigenic prostaglandins (especially $\mathrm{PGE}_{2}$ ) in cancer is also the mechanistic basis for their cardiovascular side effects; in this case, the inhibition of endothelial cell derived prostacyclin [165].

The inhibition of 11ß-hydroxysteroid dehydrogenase (11ßHSD2) may provide a new and safe anti-tumorigenic strategy [166]. 11ßHSD2 converts glucocorticoids to their inactive keto forms. Glucocorticoids are natural inhibitors of COX-2 expression; however, systemic administration of glucocorticoids is not a suitable anti-tumorigenic therapy due to immunosuppression and other side effects of steroid therapy. Thus, inhibition of 11ßHSD2 might indirectly lead to inhibition of COX-2 by increasing endogenous and local levels of glucocorticoids. The exciting findings that (a) inhibition of $11 \beta \mathrm{HSD} 2$ by a component of licorice (glycyrrizic acid) reduces tumor COX-2 activity, tumor growth, and metastasis by increasing glucocorticoid-mediated suppression COX-2 and (b) these events are not associated with the adverse gastrointestinal and cardiovascular side effects associated with NSAIDs and selective COX-2 inhibitors suggest that the licorice component could be developed as novel and possibly safe COX-2 inhibitor [166]. Like licorice, other natural compounds have been proposed as safe COX-2 inhibitors [167]. The phytoalexin resveratrol (found in grapes), the flavonoid epigallocathechin gallate (EGCG, found in green tea), the flavone apigenin (found in chamomile), and tyrosol (found in olive oil extract) represent four promising anti-tumorigenic compounds. Resveratrol can prevent skin tumor formation [168] and inhibit COX-2 transcription and activity in tumor cells [169]. EGCG exerts anticancer properties by repressing COX-2 expression both in vitro and in vivo, thus protecting from chemical-induced skin cancer [170]. Apigenin inhibits COX-2 expression by altering NF-KB pathway [171]. Finally, tyrosol has been shown to inhibit tumor cell proliferation in vitro by affecting $\mathrm{p} 38$ MAPK and CREB phosphorylation [172]. A comprehensive list of natural COX-2 inhibitor compounds found in various types of food, including garlic, onion, and pineapple, is described by Cerella and colleagues [167]. 


\subsection{Dual COX and LOX inhibitors in cancer}

Given that arachidonic acid can be metabolized by three different major enzymes (see Fig. 1 for details), it is conceivable that inhibition of one single pathway (i.e., COX-2) might not be beneficial or have unwanted side effect by shunting arachidonic acid metabolism towards the LOX or cytochrome $\mathrm{P} 450$ pathways. This in turn could lead to the production of protumorigenic (i.e., HETEs), proangiogenic (i.e., EETs), or pro-thrombotic (thromboxane) eicosanoids. Another problem related to the use of single inhibitors is that tumor cells can adjust to inhibitor treatment by upregulating the targeted enzyme. In this regard, while selective COX-2 inhibition initially delays breast cancer tumor growth, a rapid increase in tumor growth rate is evident at late stages of treatment, due to upregulation of COX-2 by the tumor cells [173]. Thus, blocking two major pathways involved in carcinogenesis, namely the LOX and COX pathways, might be a plausible approach to better inhibit cancer progression. Dual inhibition can be achieved by simultaneous treatment with COX and LOX inhibitors. This strategy has been successful in increasing more efficiently tumor cell death in vitro compared to single inhibitor treatment [98], as well as to suppress colon cancer formation induced by cigarette smoke [174]. One pitfall with this regiment is that the two inhibitors need to be administered simultaneously, thus increasing the risk of cytotoxicity and/or side effects. A solution to the problem could be the generation of a single drug with a double target. Natural as well as chemical molecules have recently emerged as promising dual COX/ LOX inhibitors. Among the chemical compounds, licofelone is a dual COX/5LOX inhibitor that leads to decreased levels of $\mathrm{PGE}_{2}$ and $\mathrm{LTB}_{4}$ without the gastrointestinal side effects linked to the use of NSAIDs [175, 176]. Although this inhibitor has been considered as an alternative to NSAIDs for the treatment of osteoarthritis, its antiinflammatory action could be also beneficial to treat cancer. Another promising molecule is propynone 50, a new class of diarylpropynones that can target three major enzymes involved in AA pathway, namely COX-2, 5-LOX, and 15-LOX [177]. A comprehensive list of chemically derived dual COX/LOX inhibitors is reviewed by Rao and Knaus [178].

Among the natural compounds, curcumin-the principal constituent of turmeric (a rhizomatous herbaceous plant of the ginger family) — downregulates LOX and COX-2 at the transcriptional level, thus making curcumin an excellent anti-inflammatory and potentially anticarcinogenic compound [179]. Interestingly, curcumin has also been described to be an inhibitor of the enzymatic activities of COX-2 and 5-LOX [180, 181], and, furthermore, to be a co-substrate for the peroxidase activity of COX-2 [182], implying that the interactions between curcumin and eicosanoid biosynthesis are highly complex. Curcumin induces apoptosis of various tumor cell lines and inhibits intrahepatic metastases of hepatocellular carcinoma cells in mice [183]. Although this natural compound is not yet used as anticancer drug in clinics, a study aimed to evaluate curcumin toxicity has revealed histologic improvement of precancerous lesions in patients with resected bladder cancer, oral leucoplakia, and intestinal metaplasia of the stomach [184]. In addition to curcumin, the dual COX/LOX inhibitor 7-tert-butyl-2, 3-dihydro-3, 3-dimethyl substituted dihydrofuran 30 inhibits both in in vitro and in vivo growth of pancreatic cancer cells by reducing the expression of COX-2, 5-LOX, and the proangiogenic factor VEGF [185]. Using indomethacin (a COX-1 and COX-2 inhibitor) as template, new $N$-aroyltetrahydro- $\gamma$ carbolines intended to inhibit both 5-LOX and COXs have been designed. Promising results indicate that some of these new compounds have the ability to suppress proliferation of prostate cancer cells in vitro [186]. Finally, although most of the dual inhibitors target COX-2 and LOX, an effort has been also made to design dual COX-1/LOX inhibitors, such as acrylic acid derivatives [187]. As these compounds might prevent COX1-mediated platelet aggregation and LOX-mediated inflammatory activity, they might be potentially used as anticancer agents. 
Although dual COX/LOX inhibition might be promising, there are also some pitfalls that need to be taken into account. One important mediator in the activation of the arachidonic acid pathways is PPARgamma. Both LOX-and COX-derived products can act as endogenous ligand of this anti-proliferative and anti-tumorigenic receptor. Thus, blocking COX/LOX might result in decreased PPARgamma activation and paradoxically in a protumorigenic effect. Thus, combination therapies based on inhibition of COX/LOX pathways together with activation or PPARgamma could be considered as an option for certain types of cancer, as suggested by Tauler and Mulshine [188].

\section{Conclusions}

In this review, we have focused on the role of two major arachidonic acid pathways, the COX and the LOX pathways, in tumorigenesis. In general, COX and LOX contribute to tumorigenesis by directly promoting tumor cell proliferation, growth, and survival. These results together with the finding that upregulation of COX and LOX expression is often observed in cancer, seem to justify the use of COX and/or LOX inhibitors as antitumorigenic agents. Although these inhibitors are available and seem to be efficient in slowing and/or preventing cancer formation, it is important to acknowledge that some of them have serious adverse side effects. The cardiovascular side effects associated with selective COX-2 inhibitors are a clear example that questions their use in clinics. In addition, the potential for non-COX-dependent antitumor effects of NSAIDs [189, 190] challenge the mechanism of action of these drugs and the role of COX-derived products in human cancer. Moreover, the pro-tumorigenic effects exerted by some arachidonic acidderived products are tumor type specific, thus making it difficult to have a uniform antitumorigenic regiment. Finally, some COX-derived products such as prostacyclin protect from tumor development and maneuvers aimed to enhance—-rather than inhibit—-their synthesis can be viewed as a potential anti-tumorigenic therapy. The picture is also complicated by the fact that COX and/or LOX might also act as "double edge sword", as they exert both tumor-suppressive and tumor-stimulatory effects, as observed for the 15LOX isoforms, thus making these enzymes "difficult" targets for anti-tumorigenic therapy. In addition, despite an initial beneficial effect of some COX inhibitors, tumors ultimately are able to escape COX inhibition. This effect is due to the ability of tumor cells to upregulate the expression of the targeted enzyme or the expression of potent pro-angiogenic or proinflammatory factors. Indeed, COX and LOX products can indirectly promote tumorigenesis by modifying the surrounding microenvironment. In this regard, COX and LOX products can be pro-tumorigenic by enhancing angiogenesis. LOX products can directly regulate endothelial cell functions, while COX-derived metabolites can regulate the synthesis of proteinases contributing to endothelial cell migration and invasion. In addition, COX and LOX can promote tumorigenesis by affecting the immune system. Some COX and/or LOX isoforms are expressed predominantly by immune cells and their products can exert proinflammatory responses. Given that the type of infiltrating cell (i.e., $\mathrm{T}$ regulatory, $\mathrm{T}$ effectors, natural killers, macrophages, neutrophils, and granulocytes) highly dictates whether tumor growth is exacerbated or inhibited, understanding how COX and LOX control immune responses is key to determining the potential use of inhibitors as anticancer therapy [89].

Another key point to consider in targeting arachidonic acid-derived pathways in tumorigenesis is that inhibition of one single pathway (i.e., COX-2) might not be beneficial or have unwanted side effect by shunting the arachidonic acid metabolism towards the LOX or cytochrome P450 pathways. Thus, the use of double inhibitors has the potential to increase efficacy, selectively and potentially overcome some side effects due to single inhibition. However, the use of dual inhibitors comes with the recognition that these inhibitors might block the synthesis of eicosanoids with direct and/or indirect anti- 
tumorigenic action. As addressed above, blocking COX and LOX might prevent the formation of natural PPARgamma ligands, thus preventing the anti-proliferative effects of this nuclear receptor. Multiple combination therapies (i.e., COX/LOX inhibitors and PPARgamma ligands or COX/LOX inhibitors and anti-TNFalpha therapies) might represent novel approaches for the development of more effective anti-tumorigenic therapies. Despite these promising solutions, the development of safe, well-tolerated, efficient, and "on" target antitumorigenic drugs still presents a major challenge.

\section{Acknowledgments}

These studies were in part supported by a Merit Review from the Department of Veterans Affairs (AP) and the NIH grants 2P01DK065123 (AP); 2PO1DK38226 (AP); the O'Brien P30DK79341-01 (AP); and GM076592 (CS).

\section{Abbreviations}

$\begin{array}{ll}\text { COX } & \text { Cyclooxygenase } \\ \text { LOX } & \text { Lipoxygenase } \\ \text { PGE }_{2} & \text { Prostaglandin } \mathrm{E}_{2} \\ \text { PGI }_{2} & \text { Prostacyclin } \\ \text { PGF }_{2} \text { a } & \text { Prostaglandin } \mathrm{F}_{2 \mathrm{a}} \\ \text { TxA }_{2} & \text { Thromboxane } \mathrm{A}_{2} \\ \text { EP } & \text { Prostaglandin E receptor } \\ \text { HK } & \text { Cyclic hemiketal eicosanoid } \\ \text { NSAID } & \text { Nonsteroidal anti-inflammatory drug } \\ \text { LTB } & \text { Leukotriene } \mathrm{B}_{4} \\ \text { HODE } & \text { Hydroxyoctadecadienoic acid } \\ \text { PGD } & \text { Prostaglandin } \mathrm{D}_{2} \\ \text { VEGF } & \text { Vascular endothelial growth factor } \\ \text { NF-KB } & \text { Nuclear factor-kappaB } \\ \text { PI3K/Akt } & \text { Phospatidylinositol-3-kinase/Akt } \\ \text { PPAR } & \text { Peroxisome proliferator-activated receptor } \\ \text { TNF } & \text { Tumor necrosis factor }\end{array}$

\section{References}

1. Wang D, Dubois RN. Eicosanoids and cancer. Nature Reviews Cancer. 2010; 10:181-193.

2. Williams CS, Luongo C, Radhika A, Zhang T, Lamps LW, Nanney LB, et al. Elevated cyclooxygenase-2 levels in Min mouse adenomas. Gastroenterology. 1996; 111:1134-1140. [PubMed: 8831610]

3. Eberhart CE, Coffey RJ, Radhika A, Giardiello FM, Ferrenbach S, DuBois RN. Up-regulation of cyclooxygenase 2 gene expression in human colorectal adenomas and adenocarcinomas. Gastroenterology. 1994; 107:1183-1188. [PubMed: 7926468]

4. Chen WS, Wei SJ, Liu JM, Hsiao M, Kou-Lin J, Yang WK. Tumor invasiveness and liver metastasis of colon cancer cells correlated with cyclooxygenase-2 (COX-2) expression and inhibited by a COX-2-selective inhibitor, etodolac. International Journal of Cancer. 2001; 91:894899. 
5. Gately S. The contributions of cyclooxygenase-2 to tumor angiogenesis. Cancer Metastasis Reviews. 2000; 19:19-27. [PubMed: 11191059]

6. Gately S, Li WW. Multiple roles of COX-2 in tumor angiogenesis: a target for antiangiogenic therapy. Seminars in Oncology. 2004; 31:2-11. [PubMed: 15179620]

7. Rizzo MT. Cyclooxygenase-2 in oncogenesis. Clinica Chimica Acta. 2011; 412:671-687.

8. Oshima M, Dinchuk JE, Kargman SL, Oshima H, Hancock B, Kwong E, et al. Suppression of intestinal polyposis in Apc delta716 knockout mice by inhibition of cyclooxygenase 2 (COX-2). Cell. 1996; 87:803-809. [PubMed: 8945508]

9. Oshima M, Murai N, Kargman S, Arguello M, Luk P, Kwong E, et al. Chemoprevention of intestinal polyposis in the Apcdelta716 mouse by rofecoxib, a specific cyclooxygenase-2 inhibitor. Cancer Research. 2001; 61:1733-1740. [PubMed: 11245490]

10. Rundhaug JE, Fischer SM. Cyclo-oxygenase-2 plays a critical role in UV-induced skin carcinogenesis. Photochemistry and Photobiology. 2008; 84:322-329. [PubMed: 18194346]

11. Stasinopoulos I, O'Brien DR, Wildes F, Glunde K, Bhujwalla ZM. Silencing of cyclooxygenase-2 inhibits metastasis and delays tumor onset of poorly differentiated metastatic breast cancer cells. Molecular Cancer Research. 2007; 5:435-442. [PubMed: 17510310]

12. Ghosh N, Chaki R, Mandal V, Mandal SC. COX-2 as a target for cancer chemotherapy. Pharmacological Reports. 2010; 62:233-244. [PubMed: 20508278]

13. Diczfalusy U, Falardeau P, Hammarstrom S. Conversion of prostaglandin endoperoxides to C17hydroxy acids catalyzed by human platelet thromboxane synthase. FEBS Letters. 1977; 84:271274. [PubMed: 598509]

14. Nakahata N. Thromboxane A2: physiology/pathophysiology, cellular signal transduction and pharmacology. Pharmacology and Therapeutics. 2008; 118:18-35. [PubMed: 18374420]

15. Cathcart MC, Gately K, Cummins R, Kay E, O'Byrne KJ, Pidgeon GP. Examination of thromboxane synthase as a prognostic factor and therapeutic target in nonsmall cell lung cancer. Molecular Cancer. 2011; 10:25. [PubMed: 21388528]

16. Huang RY, Chen GG. Cigarette smoking, cyclooxygenase-2 pathway and cancer. Biochimica et Biophysica Acta. 2011; 1815:158-169. [PubMed: 21147199]

17. Huang RY, Li MY, Hsin MK, Underwood MJ, Ma LT, Mok TS, et al. 4-Methylnitrosamino-1-3pyridyl-1-butanone (NNK) promotes lung cancer cell survival by stimulating thromboxane A2 and its receptor. Oncogene. 2011; 30:106-116. [PubMed: 20818420]

18. Leung KC, Li MY, Leung BC, Hsin MK, Mok TS, Underwood MJ, et al. Thromboxane synthase suppression induces lung cancer cell apoptosis via inhibiting NF-kappaB. Experimental Cell Research. 2010; 316:3468-3477. [PubMed: 20647010]

19. Wei J, Yan W, Li X, Ding Y, Tai HH. Thromboxane receptor alpha mediates tumor growth and angiogenesis via induction of vascular endothelial growth factor expression in human lung cancer cells. Lung Cancer. 2010; 69:26-32. [PubMed: 19853959]

20. Wei J, Yan W, Li X, Chang WC, Tai HH. Activation of thromboxane receptor alpha induces expression of cyclooxygenase-2 through multiple signaling pathways in A549 human lung adenocarcinoma cells. Biochemical Pharmacology. 2007; 74:787-800. [PubMed: 17632087]

21. Li X, Tai HH. Activation of thromboxane A(2) receptors induces orphan nuclear receptor Nurr1 expression and stimulates cell proliferation in human lung cancer cells. Carcinogenesis. 2009; 30:1606-1613. [PubMed: 19570744]

22. Schmidt NO, Ziu M, Cargioli T, Westphal M, Giese A, Black PM, et al. Inhibition of thromboxane synthase activity improves glioblastoma response to alkylation chemotherapy. Transl Oncol. 2010; 3:43-49. [PubMed: 20165694]

23. Schauff AK, Kim EL, Leppert J, Nadrowitz R, Wuestenberg R, Brockmann MA, et al. Inhibition of invasion-associated thromboxane synthase sensitizes experimental gliomas to gamma-radiation. Journal of Neuro-Oncology. 2009; 91:241-249. [PubMed: 18825315]

24. Cathcart MC, Reynolds JV, O'Byrne KJ, Pidgeon GP. The role of prostacyclin synthase and thromboxane synthase signaling in the development and progression of cancer. Biochimica et Biophysica Acta. 2010; 1805:153-166. [PubMed: 20122998]

25. Tennis MA, Vanscoyk M, Keith RL, Winn RA. The role of prostacyclin in lung cancer. Translational Research. 2010; 155:57-61. [PubMed: 20129485] 
26. Keith RL, Miller YE, Hudish TM, Girod CE, Sotto-Santiago S, Franklin WA, et al. Pulmonary prostacyclin synthase overexpression chemoprevents tobacco smoke lung carcinogenesis in mice. Cancer Research. 2004; 64:5897-5904. [PubMed: 15313935]

27. Keith RL, Karoor V, Mozer AB, Hudish TM, Le M, Miller YE. Chemoprevention of murine lung cancer by gefitinib in combination with prostacyclin synthase overexpression. Lung Cancer. 2010; 70:37-42. [PubMed: 20116128]

28. Frigola J, Munoz M, Clark SJ, Moreno V, Capella G, Peinado MA. Hypermethylation of the prostacyclin synthase (PTGIS) promoter is a frequent event in colorectal cancer and associated with aneuploidy. Oncogene. 2005; 24:7320-7326. [PubMed: 16007128]

29. Pehlivan Y, Turkbeyler IH, Balakan O, Sevinc A, Yilmaz M, Bakir K, Onat AM. Possible antimetastatic effect of Iloprost in a patient with systemic sclerosis with lung cancer: a case study. Rheumatol Int. 2011 (in press).

30. Laubli H, Borsig L. Selectins as mediators of lung metastasis. Cancer Microenvironment. 2010; 3:97-105. [PubMed: 21209777]

31. Mohle R, Green D, Moore MA, Nachman RL, Rafii S. Constitutive production and thrombininduced release of vascular endothelial growth factor by human megakaryocytes and platelets. Proceedings of the National Academy of Sciences of the United States of America. 1997; 94:663668. [PubMed: 9012841]

32. Tennis MA, Van Scoyk M, Heasley LE, Vandervest K, Weiser-Evans M, Freeman S, et al. Prostacyclin inhibits non-small cell lung cancer growth by a frizzled 9-dependent pathway that is blocked by secreted frizzled-related protein 1. Neoplasia. 2010; 12:244-253. [PubMed: 20234818]

33. Nemenoff R, Meyer AM, Hudish TM, Mozer AB, Snee A, Narumiya S, et al. Prostacyclin prevents murine lung cancer independent of the membrane receptor by activation of peroxisomal proliferator-activated receptor Y. Cancer Prevention Research (Philadelphia, Pa.). 2008; 1:349356.

34. Hata AN, Lybrand TP, Breyer RM. Identification of determinants of ligand binding affinity and selectivity in the prostaglandin D2 receptor CRTH2. Journal of Biological Chemistry. 2005; 280:32442-32451. [PubMed: 16030019]

35. Hirai H, Abe H, Tanaka K, Takatsu K, Sugamura K, Nakamura M, et al. Gene structure and functional properties of mouse CRTH2, a prostaglandin D2 receptor. Biochemical and Biophysical Research Communications. 2003; 307:797-802. [PubMed: 12878180]

36. Wright DH, Nantel F, Metters KM, Ford-Hutchinson AW. A novel biological role for prostaglandin D2 is suggested by distribution studies of the rat DP prostanoid receptor. European Journal of Pharmacology. 1999; 377:101-115. [PubMed: 10448933]

37. Ragolia L, Palaia T, Hall CE, Klein J, Buyuk A. Diminished lipocalin-type prostaglandin D(2) synthase expression in human lung tumors. Lung Cancer. 2010; 70:103-109. [PubMed: 20144489]

38. Takeda K, Takahashi NH, Yoshizawa M, Shibahara S. Lipocalin-type prostaglandin D synthase as a regulator of the retinoic acid signalling inmelanocytes. Journal of Biochemistry. 2010; 148:139 148. [PubMed: 20403807]

39. Dionne S, Levy E, Levesque D, Seidman EG. PPARgamma ligand 15-deoxy-delta 12,14prostaglandin J2 sensitizes human colon carcinoma cells to TWEAK-induced apoptosis. Anticancer Research. 2010; 30:157-166. [PubMed: 20150631]

40. Wang JJ, Mak OT. Induction of apoptosis by 15d-PGJ2 via ROS formation: an alternative pathway without PPARgamma activation in non-small cell lung carcinoma A549 cells. Prostaglandins \& Other Lipid Mediators. 2011; 94:104-111. [PubMed: 21396480]

41. Passeron T, Valencia JC, Namiki T, Vieira WD, Passeron H, Miyamura Y, et al. Upregulation of SOX9 inhibits the growth of human and mouse melanomas and restores their sensitivity to retinoic acid. The Journal of Clinical Investigation. 2009; 119:954-963. [PubMed: 19273910]

42. Murata T, Lin MI, Aritake K, Matsumoto S, Narumiya S, Ozaki H, et al. Role of prostaglandin D2 receptor DP as a suppressor of tumor hyperpermeability and angiogenesis in vivo. Proceedings of the National Academy of Sciences of the United States of America. 2008; 105:20009-20014. [PubMed: 19060214] 
43. Kliewer SA, Lenhard JM, Willson TM, Patel I, Morris DC, Lehmann JM. A prostaglandin J2 metabolite binds peroxisome proliferator-activated receptor gamma and promotes adipocyte differentiation. Cell. 1995; 83:813-819. [PubMed: 8521498]

44. Pozzi A, Capdevila JH. PPARa ligands as antitumorigenic and antiangiogenic agents. PPAR Res. 2008; 2008 Article ID 906542.

45. Diers AR, Dranka BP, Ricart KC, Oh JY, Johnson MS, Zhou F, et al. Modulation of mammary cancer cell migration by 15-deoxy-delta(12,14)-prostaglandin $\mathrm{J}(2)$ : implications for anti-metastatic therapy. Biochemical Journal. 2010; 430:69-78. [PubMed: 20536428]

46. Koyama M, Izutani Y, Goda AE, Matsui TA, Horinaka M, Tomosugi M, et al. Histone deacetylase inhibitors and 15-deoxy-Delta12,14-prostaglandin J2 synergistically induce apoptosis. Clinical Cancer Research. 2010; 16:2320-2332. [PubMed: 20371690]

47. Shim J, Kim BH, Kim YI, Kim KY, Hwangbo Y, Jang JY, et al. The peroxisome proliferatoractivated receptor gamma ligands, pioglitazone and 15-deoxy-Delta (12,14)-prostaglandin $\mathrm{J}(2)$, have antineoplastic effects against hepatitis B virus-associated hepatocellular carcinoma cells. International Journal of Oncology. 2010; 36:223-231. [PubMed: 19956851]

48. Cocca C, Dorado J, Calvo E, Lopez JA, Santos A, Perez-Castillo A. 15-Deoxi-Delta(12,14)prostaglandin $\mathrm{J} 2$ is a tubulin-binding agent that destabilizes microtubules and induces mitotic arrest. Biochemical Pharmacology. 2009; 78:1330-1339. [PubMed: 19576185]

49. Coyle AT, O'Keeffe MB, Kinsella BT. 15-deoxy Delta12,14-prostaglandin J2 suppresses transcription by promoter 3 of the human thromboxane A2 receptor gene through peroxisome proliferator-activated receptor gamma in human erythroleukemia cells. FEBS Journal. 2005; 272:4754-4773. [PubMed: 16156795]

50. Rossi A, Kapahi P, Natoli G, Takahashi T, Chen Y, Karin M, et al. Anti-inflammatory cyclopentenone prostaglandins are direct inhibitors of IkappaB kinase. Nature. 2000; 403:103108. [PubMed: 10638762]

51. Dutta J, Fan Y, Gupta N, Fan G, Gelinas C. Current insights into the regulation of programmed cell death by NF-kappaB. Oncogene. 2006; 25:6800-6816. [PubMed: 17072329]

52. Keightley MC, Sales KJ, Jabbour HN. PGF2alpha-F-prostanoid receptor signalling via ADAMTS1 modulates epithelial cell invasion and endothelial cell function in endometrial cancer. BMC Cancer. 2010; 10:488. [PubMed: 20840749]

53. Sales KJ, List T, Boddy SC, Williams AR, Anderson RA, Naor Z, et al. A novel angiogenic role for prostaglandin F2alpha-FP receptor interaction in human endometrial adenocarcinomas. Cancer Research. 2005; 65:7707-7716. [PubMed: 16140938]

54. Sales KJ, Boddy SC, Williams AR, Anderson RA, Jabbour HN. F-prostanoid receptor regulation of fibroblast growth factor 2 signaling in endometrial adenocarcinoma cells. Endocrinology. 2007; 148:3635-3644. [PubMed: 17478553]

55. Jabbour HN, Sales KJ, Boddy SC, Anderson RA, Williams AR. A positive feedback loop that regulates cyclooxygenase-2 expression and prostaglandin F2alpha synthesis via the F-seriesprostanoid receptor and extracellular signalregulated kinase 1/2 signaling pathway. Endocrinology. 2005; 146:4657-4664. [PubMed: 16081631]

56. Sales KJ, Boddy SC, Jabbour HN. F-prostanoid receptor alters adhesion, morphology and migration of endometrial adenocarcinoma cells. Oncogene. 2008; 27:2466-2477. [PubMed: 17968320]

57. Wallace AE, Catalano RD, Anderson RA, Jabbour HN. Chemokine (C-C) motif ligand 20 is regulated by $\mathrm{PGF}$ (2alpha)-F-prostanoid receptor signalling in endometrial adenocarcinoma and promotes cell proliferation. Molecular and Cellular Endocrinology. 2011; 331:129-135. [PubMed: 20816914]

58. Sales KJ, Maldonado-Perez D, Grant V, Catalano RD, Wilson MR, Brown P, et al. Prostaglandin F (2alpha)-F-prostanoid receptor regulates CXCL8 expression in endometrial adenocarcinoma cells via the calciumcalcineurin-NFAT pathway. Biochimica et Biophysica Acta. 2009; 1793:19171928. [PubMed: 19819266]

59. Wallace AE, Sales KJ, Catalano RD, Anderson RA, Williams AR, Wilson MR, et al. Prostaglandin F2alpha-F-prostanoid receptor signaling promotes neutrophil chemotaxis via chemokine (C-X-C 
motif) ligand 1 in endometrial adenocarcinoma. Cancer Research. 2009; 69:5726-5733. [PubMed: 19549892]

60. Sugimoto Y, Narumiya S. Prostaglandin E receptors. Journal of Biological Chemistry. 2007; 282:11613-11617. [PubMed: 17329241]

61. Breyer RM, Bagdassarian CK, Myers SA, Breyer MD. Prostanoid receptors: subtypes and signaling. Annual Review of Pharmacology and Toxicology. 2001; 41:661-690.

62. Nakanishi M, Menoret A, Tanaka T, Miyamoto S, Montrose DC, Vella A, Rosenberg DW. Selective PGE2 suppression impairs colon carcinogenesis and modifies local mucosal immunity. Cancer Prev Res (Phila). 2011; 4(8):1198-1208. [PubMed: 21576350]

63. Hanaka H, Pawelzik SC, Johnsen JI, Rakonjac M, Terawaki K, Rasmuson A, et al. Microsomal prostaglandin E synthase 1 determines tumor growth in vivo of prostate and lung cancer cells. Proceedings of the National Academy of Sciences of the United States of America. 2009; 106:18757-18762. [PubMed: 19846775]

64. Regan JW. EP2 and EP4 prostanoid receptor signaling. Life Sciences. 2003; 74:143-153. [PubMed: 14607241]

65. Fujino H, Xu W, Regan JW. Prostaglandin E2 induced functional expression of early growth response factor-1 by EP4, but not EP2, prostanoid receptors via the phosphatidylinositol 3-kinase and extracellular signal-regulated kinases. Journal of Biological Chemistry. 2003; 278:1215112156. [PubMed: 12566441]

66. Pozzi A, Yan X, Macias-Perez I, Wei S, Hata AN, Breyer RM, et al. Colon carcinoma cell growth is associated with prostaglandin E2/EP4 receptor-evoked ERK activation. Journal of Biological Chemistry. 2004; 279:29797-29804. [PubMed: 15123663]

67. Macias-Perez IM, Zent R, Carmosino M, Breyer MD, Breyer RM, Pozzi A. Mouse EP3 alpha, beta, and gamma receptor variants reduce tumor cell proliferation and tumorigenesis in vivo . Journal of Biological Chemistry. 2008; 283:12538-12545. [PubMed: 18230618]

68. Surh I, Rundhaug J, Pavone A, Mikulec C, Abel E, Fischer SM. Upregulation of the EP1 receptor for prostaglandin E(2) promotes skin tumor progression. Molecular Carcinogenesis. 2011; 50:458468. [PubMed: 21268127]

69. Yang SF, Chen MK, Hsieh YS, Chung TT, Hsieh YH, Lin CW, et al. Prostaglandin E2/EP1 signaling pathway enhances intercellular adhesion molecule 1 (ICAM-1) expression and cell motility in oral cancer cells. Journal of Biological Chemistry. 2010; 285:29808-29816. [PubMed: 20647315]

70. Liu JF, Fong YC, Chang CS, Huang CY, Chen HT, Yang WH, et al. Cyclooxygenase-2 enhances alpha2beta1 integrin expression and cell migration via EP1 dependent signaling pathway in human chondrosarcoma cells. Molecular Cancer. 2010; 9:43. [PubMed: 20178602]

71. Ma X, Kundu N, Ioffe OB, Goloubeva O, Konger R, Baquet C, et al. Prostaglandin E receptor EP1 suppresses breast cancer metastasis and is linked to survival differences and cancer disparities. Molecular Cancer Research. 2010; 8:1310-1318. [PubMed: 20858737]

72. Axelsson H, Lonnroth C, Wang W, Svanberg E, Lundholm K. Cyclooxygenase inhibition in early onset of tumor growth and related angiogenesis evaluated in EP1 and EP3 knockout tumor-bearing mice. Angiogenesis. 2005; 8:339-348. [PubMed: 16400521]

73. Sung YM, He G, Fischer SM. Lack of expression of the EP2 but not EP3 receptor for prostaglandin E2 results in suppression of skin tumor development. Cancer Research. 2005; 65:9304-9311. [PubMed: 16230392]

74. Tian M, Schiemann WP. PGE2 receptor EP2 mediates the antagonistic effect of COX-2 on TGFbeta signaling during mammary tumorigenesis. The FASEB Journal. 2010; 24:1105-1116.

75. Kuo KT, Wang HW, Chou TY, Hsu WH, Hsu HS, Lin CH, et al. Prognostic role of PGE2 receptor EP2 in esophageal squamous cell carcinoma. Annals of Surgical Oncology. 2009; 16:352-360. [PubMed: 19050969]

76. Takahashi T, Ogawa H, Izumi K, Uehara H. The soluble EP2 receptor FuEP2/Ex2 suppresses endometrial cancer cell growth in an orthotopic xenograft model in nude mice. Cancer Letters. 2011; 306:67-75. [PubMed: 21419570] 
77. Kubo H, Hosono K, Suzuki T, Ogawa Y, Kato H, Kamata H, et al. Host prostaglandin EP3 receptor signaling relevant to tumor-associated lymphangiogenesis. Biomedicine and Pharmacotherapy. 2010; 64:101-106. [PubMed: 20034758]

78. Amano H, Ito Y, Suzuki T, Kato S, Matsui Y, Ogawa F, et al. Roles of a prostaglandin E-type receptor, EP3, in upregulation of matrix metalloproteinase-9 and vascular endothelial growth factor during enhancement of tumor metastasis. Cancer Science. 2009; 100:2318-2324. [PubMed: 19799610]

79. Amano H, Hayashi I, Endo H, Kitasato H, Yamashina S, Maruyama T, et al. Host prostaglandin E(2)-EP3 signaling regulates tumor-associated angiogenesis and tumor growth. The Journal of Experimental Medicine. 2003; 197:221-232. [PubMed: 12538661]

80. Shoji Y, Takahashi M, Kitamura T, Watanabe K, Kawamori T, Maruyama T, et al. Downregulation of prostaglandin E receptor subtype EP3 during colon cancer development. Gut. 2004; 53:1151-1158. [PubMed: 15247185]

81. Segi E, Sugimoto Y, Yamasaki A, Aze Y, Oida H, Nishimura T, et al. Patent ductus arteriosus and neonatal death in prostaglandin receptor EP4-deficient mice. Biochemical and Biophysical Research Communications. 1998; 246:7-12. [PubMed: 9600059]

82. Cherukuri DP, Chen XB, Goulet AC, Young RN, Han Y, Heimark RL, et al. The EP4 receptor antagonist, L-161,982, blocks prostaglandin E2-induced signal transduction and cell proliferation in HCA-7 colon cancer cells. Experimental Cell Research. 2007; 313:2969-2979. [PubMed: 17631291]

83. Hawcroft G, Ko CW, Hull MA. Prostaglandin E2-EP4 receptor signalling promotes tumorigenic behaviour of HT-29 human colorectal cancer cells. Oncogene. 2007; 26:3006-3019. [PubMed: 17130837]

84. Kim JI, Lakshmikanthan V, Frilot N, Daaka Y. Prostaglandin E2 promotes lung cancer cell migration via EP4-betaArrestin1-c-Src signalsome. Molecular Cancer Research. 2010; 8:569-577. [PubMed: 20353998]

85. Yang L, Huang Y, Porta R, Yanagisawa K, Gonzalez A, Segi E, et al. Host and direct antitumor effects and profound reduction in tumor metastasis with selective EP4 receptor antagonism. Cancer Research. 2006; 66:9665-9672. [PubMed: 17018624]

86. Terada N, Shimizu Y, Kamba T, Inoue T, Maeno A, Kobayashi T, et al. Identification of EP4 as a potential target for the treatment of castration-resistant prostate cancer using a novel xenograft model. Cancer Research. 2010; 70:1606-1615. [PubMed: 20145136]

87. Schneider A, Guan Y, Zhang Y, Magnuson MA, Pettepher C, Loftin CD, et al. Generation of a conditional allele of the mouse prostaglandin EP4 receptor. Genesis. 2004; 40:7-14. [PubMed: 15354288]

88. Rao R, Redha R, Macias-Perez I, Su Y, Hao C, Zent R, et al. Prostaglandin E2-EP4 receptor promotes endothelial cell migration via ERK activation and angiogenesis in vivo. Journal of Biological Chemistry. 2007; 282:16959-16968. [PubMed: 17401137]

89. Pidgeon GP, Lysaght J, Krishnamoorthy S, Reynolds JV, O'Byrne K, Nie D, et al. Lipoxygenase metabolism: roles in tumor progression and survival. Cancer Metastasis Reviews. 2007; 26:503524. [PubMed: 17943411]

90. Soberman RJ, Harper TW, Betteridge D, Lewis RA, Austen KF. Characterization and separation of the arachidonic acid 5-lipoxygenase and linoleic acid omega-6 lipoxygenase (arachidonic acid 15lipoxygenase) of human polymorphonuclear leukocytes. Journal of Biological Chemistry. 1985; 260:4508-4515. [PubMed: 3920219]

91. Bannenberg G, Serhan CN. Specialized proresolving lipid mediators in the inflammatory response: an update. Biochimica et Biophysica Acta. 2010; 1801:1260-1273. [PubMed: 20708099]

92. Wasilewicz MP, Kolodziej B, Bojulko T, Kaczmarczyk M, Sulzyc-Bielicka V, Bielicki D, et al. Overexpression of 5-lipoxygenase in sporadic colonic adenomas and a possible new aspect of colon carcinogenesis. International Journal of Colorectal Disease. 2010; 25:1079-1085. [PubMed: 20549218]

93. Melstrom LG, Bentrem DJ, Salabat MR, Kennedy TJ, Ding XZ, Strouch M, et al. Overexpression of 5-lipoxygenase in colon polyps and cancer and the effect of 5-LOX inhibitors in vitro and in a murine model. Clinical Cancer Research. 2008; 14:6525-6530. [PubMed: 18927292] 
94. Metzger K, Angres G, Maier H, Lehmann WD. Lipoxygenase products in human saliva: patients with oral cancer compared to controls. Free Radical Biology \& Medicine. 1995; 18:185-194. [PubMed: 7744301]

95. Yang P, Sun Z, Chan D, Cartwright CA, Vijjeswarapu M, Ding J, et al. Zyflamend reduces LTB4 formation and prevents oral carcinogenesis in a 7,12-dimethylbenz[alpha] anthracene (DMBA)induced hamster cheek pouch model. Carcinogenesis. 2008; 29:2182-2189. [PubMed: 18687669]

96. Chen Y, Hu Y, Zhang H, Peng C, Li S. Loss of the Alox5 gene impairs leukemia stem cells and prevents chronic myeloid leukemia. Nature Genetics. 2009; 41:783-792. [PubMed: 19503090]

97. Shin VY, Jin HC, Ng EK, Sung JJ, Chu KM, Cho CH. Activation of 5-lipoxygenase is required for nicotine mediated epithelial-mesenchymal transition and tumor cell growth. Cancer Letters. 2010; 292:237-245. [PubMed: 20061081]

98. Schroeder CP, Yang P, Newman RA, Lotan R. Simultaneous inhibition of COX-2 and 5-LOX activities augments growth arrest and death of premalignant and malignant human lung cell lines. Journal of Experimental Therapeutics and Oncology. 2007; 6:183-192. [PubMed: 17552358]

99. Hayashi T, Nishiyama K, Shirahama T. Inhibition of 5-lipoxygenase pathway suppresses the growth of bladder cancer cells. International Journal of Urology. 2006; 13:1086-1091. [PubMed: 16903934]

100. Chen X, Wang S, Wu N, Yang CS. Leukotriene A4 hydrolase as a target for cancer prevention and therapy. Current Cancer Drug Targets. 2004; 4:267-283. [PubMed: 15134534]

101. Peters-Golden M, Brock TG. 5-Lipoxygenase and FLAP. Prostaglandins, Leukotrienes, and Essential Fatty Acids. 2003; 69:99-109.

102. Schweiger D, Furstenberger G, Krieg P. Inducible expression of 15-lipoxygenase-2 and 8lipoxygenase inhibits cell growth via common signaling pathways. Journal of Lipid Research. 2007; 48:553-564. [PubMed: 17164225]

103. Muga SJ, Thuillier P, Pavone A, Rundhaug JE, Boeglin WE, Jisaka M, et al. 8S-Lipoxygenase products activate peroxisome proliferator-activated receptor alpha and induce differentiation in murine keratinocytes. Cell Growth \& Differentiation. 2000; 11:447-454. [PubMed: 10965849]

104. Burger F, Krieg P, Kinzig A, Schurich B, Marks F, Furstenberger G. Constitutive expression of 8lipoxygenase in papillomas and clastogenic effects of lipoxygenase-derived arachidonic acid metabolites in keratinocytes. Molecular Carcinogenesis. 1999; 24:108-117. [PubMed: 10078938]

105. Hagmann W, Gao X, Zacharek A, Wojciechowski LA, Honn KV. 12-Lipoxygenase in Lewis lung carcinoma cells: molecular identity, intracellular distribution of activity and protein, and $\mathrm{Ca}(2+)-$ dependent translocation from cytosol to membranes. Prostaglandins. 1995; 49:49-62. [PubMed: 7792391]

106. Gao X, Grignon DJ, Chbihi T, Zacharek A, Chen YQ, Sakr W, et al. Elevated 12-lipoxygenase mRNA expression correlates with advanced stage and poor differentiation of human prostate cancer. Urology. 1995; 46:227-237. [PubMed: 7624992]

107. Nithipatikom K, Isbell MA, See WA, Campbell WB. Elevated 12- and 20hydroxyeicosatetraenoic acid in urine of patients with prostatic diseases. Cancer Letters. 2006; 233:219-225. [PubMed: 15882928]

108. Tang DG, Chen YQ, Honn KV. Arachidonate lipoxygenases as essential regulators of cell survival and apoptosis. Proceedings of the National Academy of Sciences of the United States of America. 1996; 93:5241-5246. [PubMed: 8643560]

109. Wong BC, Wang WP, Cho CH, Fan XM, Lin MC, Kung HF, et al. 12-Lipoxygenase inhibition induced apoptosis in human gastric cancer cells. Carcinogenesis. 2001; 22:1349-1354. [PubMed: 11532854]

110. Pidgeon GP, Kandouz M, Meram A, Honn KV. Mechanisms controlling cell cycle arrest and induction of apoptosis after 12-lipoxygenase inhibition in prostate cancer cells. Cancer Research. 2002; 62:2721-2727. [PubMed: 11980674]

111. Nie D, Hillman GG, Geddes T, Tang K, Pierson C, Grignon DJ, et al. Platelet-type 12lipoxygenase in a human prostate carcinoma stimulates angiogenesis and tumor growth. Cancer Research. 1998; 58:4047-4051. [PubMed: 9751607] 
112. Tang DG, Renaud C, Stojakovic S, Diglio CA, Porter A, Honn KV. 12(S)-HETE is a mitogenic factor for microvascular endothelial cells: its potential role in angiogenesis. Biochemical and Biophysical Research Communications. 1995; 211:462-468. [PubMed: 7540838]

113. Nie D, Tang K, Diglio C, Honn KV. Eicosanoid regulation of angiogenesis: role of endothelial arachidonate 12-lipoxygenase. Blood. 2000; 95:2304-2311. [PubMed: 10733500]

114. Nie D, Krishnamoorthy S, Jin R, Tang K, Chen Y, Qiao Y, et al. Mechanisms regulating tumor angiogenesis by 12-lipoxygenase in prostate cancer cells. Journal of Biological Chemistry. 2006; 281:18601-18609. [PubMed: 16638750]

115. Tang DG, Timar J, Grossi IM, Renaud C, Kimler VA, Diglio CA, et al. The lipoxygenase metabolite: 12(S)-HETE, induces a protein kinase C-dependent cytoskeletal rearrangement and retraction of microvascular endothelial cells. Experimental Cell Research. 1993; 207:361-375. [PubMed: 7688315]

116. Tang DG, Chen YQ, Diglio CA, Honn KV. Protein kinase C-dependent effects of 12(S)-HETE on endothelial cell vitronectin receptor and fibronectin receptor. The Journal of Cell Biology. 1993; 121:689-704. [PubMed: 7683691]

117. Brooks PC, Clark RA, Cheresh DA. Requirement of vascular integrin alpha v beta 3 for angiogenesis. Science. 1994; 264:569-571. [PubMed: 7512751]

118. Kurahashi Y, Herbertsson H, Soderstrom M, Rosenfeld MG, Hammarstrom S. A 12(S)hydroxyeicosatetraenoic acid receptor interacts with steroid receptor coactivator-1. Proceedings of the National Academy of Sciences of the United States of America. 2000; 97:5779-5783. [PubMed: 10823935]

119. Herbertsson H, Hammarstrom S. Cytosolic 12(S)-hydroxyl-5,8,10,14-eicosatetraenoic acid binding sites in carcinoma cells. Advances in Experimental Medicine and Biology. 1997; 400A: 287-293. [PubMed: 9547570]

120. Herbertsson H, Kuhme T, Evertsson U, Wigren J, Hammarstrom S. Identification of subunits of the $650 \mathrm{kDa}$ 12(S)-HETE binding complex in carcinoma cells. Journal of Lipid Research. 1998; 39:237-244. [PubMed: 9507984]

121. Herbertsson H, Kuhme T, Hammarstrom S. Subunits and cellular occurrence of the 12(S)-HETE binding complex. Advances in Experimental Medicine and Biology. 1999; 469:253-258. [PubMed: 10667338]

122. Herbertsson H, Kuhme T, Hammarstrom S. The 650-kDa 12(S)-hydroxyeicosatetraenoic acid binding complex: occurrence in human platelets, identification of hsp90 as a constituent, and binding properties of its 50-kDa subunit. Archives of Biochemistry and Biophysics. 1999; 367:33-38. [PubMed: 10375396]

123. Moreno JJ. New aspects of the role of hydroxyeicosatetraenoic acids in cell growth and cancer development. Biochemical Pharmacology. 2009; 77:1-10. [PubMed: 18761324]

124. Jiang WG, Watkins G, Douglas-Jones A, Mansel RE. Reduction of isoforms of 15-lipoxygenase (15-LOX)-1 and 15-LOX-2 in human breast cancer. Prostaglandins, Leukotrienes, and Essential Fatty Acids. 2006; 74:235-245.

125. Shureiqi I, Wu Y, Chen D, Yang XL, Guan B, Morris JS, et al. The critical role of 15lipoxygenase-1 in colorectal epithelial cell terminal differentiation and tumorigenesis. Cancer Research. 2005; 65:11486-11492. [PubMed: 16357157]

126. Freedman RS, Wang E, Voiculescu S, Patenia R, Bassett RL Jr, Deavers M, et al. Comparative analysis of peritoneum and tumor eicosanoids and pathways in advanced ovarian cancer. Clinical Cancer Research. 2007; 13:5736-5744. [PubMed: 17908963]

127. Tang DG, Bhatia B, Tang S, Schneider-Broussard R. 15-Lipoxygenase 2 (15-LOX2) is a functional tumor suppressor that regulates human prostate epithelial cell differentiation, senescence, and growth (size). Prostaglandins \& Other Lipid Mediators. 2007; 82:135-146. [PubMed: 17164141]

128. Tang S, Bhatia B, Maldonado CJ, Yang P, Newman RA, Liu J, et al. Evidence that arachidonate 15-lipoxygenase 2 is a negative cell cycle regulator in normal prostate epithelial cells. Journal of Biological Chemistry. 2002; 277:16189-16201. [PubMed: 11839751]

129. Bhatia B, Tang S, Yang P, Doll A, Aumueller G, Newman RA, et al. Cell-autonomous induction of functional tumor suppressor 15-lipoxygenase 2 (15-LOX2) contributes to replicative 
senescence of human prostate progenitor cells. Oncogene. 2005; 24:3583-3595. [PubMed: 15750631]

130. Shappell SB, Boeglin WE, Olson SJ, Kasper S, Brash AR. 15-Lipoxygenase-2 (15-LOX-2) is expressed in benign prostatic epithelium and reduced in prostate adenocarcinoma. American Journal of Pathology. 1999; 155:235-245. [PubMed: 10393855]

131. Suraneni MV, Schneider-Broussard R, Moore JR, Davis TC, Maldonado CJ, Li H, et al. Transgenic expression of 15-lipoxygenase 2 (15-LOX2) in mouse prostate leads to hyperplasia and cell senescence. Oncogene. 2010; 29:4261-4275. [PubMed: 20514017]

132. Zuo X, Wu Y, Morris JS, Stimmel JB, Leesnitzer LM, Fischer SM, et al. Oxidative metabolism of linoleic acid modulates PPAR-beta/delta suppression of PPAR-gamma activity. Oncogene. 2006; 25:1225-1241. [PubMed: 16288226]

133. Shureiqi I, Jiang W, Zuo X, Wu Y, Stimmel JB, Leesnitzer LM, et al. The 15-lipoxygenase-1 product 13-S-hydroxyoctadecadienoic acid down-regulates PPAR-delta to induce apoptosis in colorectal cancer cells. Proceedings of the: National Academy of Sciences of the United States of America. 2003; 100:9968-9973. [PubMed: 12909723]

134. Keshamouni VG, Reddy RC, Arenberg DA, Joel B, Thannickal VJ, Kalemkerian GP, et al. Peroxisome proliferator-activated receptor-gamma activation inhibits tumor progression in nonsmall-cell lung cancer. Oncogene. 2004; 23:100-108. [PubMed: 14712215]

135. Yuan H, Li MY, Ma LT, Hsin MK, Mok TS, Underwood MJ, et al. 15-Lipoxygenases and its metabolites 15(S)-HETE and 13(S)-HODE in the development of non-small cell lung cancer. Thorax. 2010; 65:321-326. [PubMed: 20388757]

136. Nixon JB, Kim KS, Lamb PW, Bottone FG, Eling TE. 15-Lipoxygenase-1 has anti-tumorigenic effects in colorectal cancer. Prostaglandins, Leukotrienes, and Essential Fatty Acids. 2004; 70:715.

137. Mao JT, Nie WX, Tsu IH, Jin YS, Rao JY, Lu QY, et al. White tea extract induces apoptosis in non-small cell lung cancer cells: the role of peroxisome proliferatoractivated receptor- $Y$ and $15-$ lipoxygenases. Cancer Prevention Research (Philadelphia, Pa.). 2010; 3:1132-1140.

138. Harats D, Ben-Shushan D, Cohen H, Gonen A, Barshack I, Goldberg I, et al. Inhibition of carcinogenesis in transgenic mouse models over-expressing 15-lipoxygenase in the vascular wall under the control of murine preproendothelin-1 promoter. Cancer Letters. 2005; 229:127-134. [PubMed: 16157225]

139. Viita H, Markkanen J, Eriksson E, Nurminen M, Kinnunen K, Babu M, et al. 15-Lipoxygenase-1 prevents vascular endothelial growth factor A- and placental growth factor-induced angiogenic effects in rabbit skeletal muscles via reduction in growth factor mRNA levels, NO bioactivity, and downregulation of VEGF receptor 2 expression. Circulation Research. 2008; 102:177-184. [PubMed: 17991885]

140. Sauer LA, Dauchy RT, Blask DE, Armstrong BJ, Scalici S. 13-Hydroxyoctadecadienoic acid is the mitogenic signal for linoleic acid-dependent growth in rat hepatoma 7288CTC in vivo. Cancer Research. 1999; 59:4688-4692. [PubMed: 10493526]

141. Kelavkar UP, Cohen C, Kamitani H, Eling TE, Badr KF. Concordant induction of 15lipoxygenase- 1 and mutant p53 expression in human prostate adenocarcinoma: correlation with Gleason staging. Carcinogenesis. 2000; 21:1777-1787. [PubMed: 11023533]

142. Kelavkar UP, Glasgow W, Olson SJ, Foster BA, Shappell SB. Overexpression of 12/15lipoxygenase, an ortholog of human 15-lipoxygenase-1, in the prostate tumors of TRAMP mice. Neoplasia. 2004; 6:821-830. [PubMed: 15720809]

143. Planaguma A, Kazani S, Marigowda G, Haworth O, Mariani TJ, Israel E, et al. Airway lipoxin A4 generation and lipoxin A4 receptor expression are decreased in severe asthma. American Journal of Respiratory and Critical Care Medicine. 2008; 178:574-582. [PubMed: 18583575]

144. Kieran NE, Maderna P, Godson C. Lipoxins: potential anti-inflammatory, proresolution, and antifibrotic mediators in renal disease. Kidney International. 2004; 65:1145-1154. [PubMed: 15086453]

145. Chen Y, Hao H, He S, Cai L, Li Y, Hu S, et al. Lipoxin A4 and its analogue suppress the tumor growth of transplanted H22 in mice: the role of antiangiogenesis. Molecular Cancer Therapeutics. 2010; 9:2164-2174. [PubMed: 20682645] 
146. Liu S, Wu P, Ye D, Huang Y, Zhou X, Li Y, et al. Effects of lipoxin A(4) on CoCl(2)-induced angiogenesis and its possible mechanisms in human umbilical vein endothelial cells. Pharmacology. 2009; 84:17-23. [PubMed: 19478549]

147. Cezar-de-Mello PF, Nascimento-Silva V, Villela CG, Fierro IM. Aspirin-triggered Lipoxin A4 inhibition of VEGF-induced endothelial cell migration involves actin polymerization and focal adhesion assembly. Oncogene. 2006; 25:122-129. [PubMed: 16132039]

148. Cezar-de-Mello PF, Vieira AM, Nascimento-Silva V, Villela CG, Barja-Fidalgo C, Fierro IM. ATL-1, an analogue of aspirin-triggered lipoxin A4, is a potent inhibitor of several steps in angiogenesis induced by vascular endothelial growth factor. British Journal of Pharmacology. 2008; 153:956-965. [PubMed: 18193074]

149. Schneider C, Boeglin WE, Yin H, Stec DF, Voehler M. Convergent oxygenation of arachidonic acid by 5-lipoxygenase and cyclooxygenase-2. Journal of the American Chemical Society. 2006; 128:720-721. [PubMed: 16417352]

150. Griesser M, Suzuki T, Tejera N, Mont S, Boeglin WE, Pozzi A, et al. Biosynthesis of hemiketal eicosanoids by cross-over of the 5-lipoxygenase and cyclooxygenase-2 pathways. Proceedings of the National Academy of Sciences of the. United States of America. 2011; 108:6945-6950.

151. Nie D, Honn KV. Cyclooxygenase, lipoxygenase and tumor angiogenesis. Cellular and Molecular Life Sciences. 2002; 59:799-807. [PubMed: 12088280]

152. Tong WG, Ding XZ, Witt RC, Adrian TE. Lipoxygenase inhibitors attenuate growth of human pancreatic cancer xenografts and induce apoptosis through the mitochondrial pathway. Molecular Cancer Therapeutics. 2002; 1:929-935. [PubMed: 12481414]

153. Agarwal S, Achari C, Praveen D, Roy KR, Reddy GV, Reddanna P. Inhibition of 12-LOX and COX-2 reduces the proliferation of human epidermoid carcinoma cells (A431) by modulating the ERK and PI3K-Akt signalling pathways. Experimental Dermatology. 2009; 18:939-946. [PubMed: 19558494]

154. Pergola C, Werz O. 5-Lipoxygenase inhibitors: a review of recent developments and patents. Expert Opinion on Therapeutic Patents. 2010; 20:355-375. [PubMed: 20180620]

155. Bolger JK, Tian W, Wolter WR, Cho W, Suckow MA, Miller MJ. Synthesis and evaluation of 5lipoxygenase translocation inhibitors from acylnitroso hetero-Diels-Alder cycloadducts. Organic and Biomolecular Chemistry. 2011; 9:2999-3010. [PubMed: 21365098]

156. Reddy NP, Aparoy P, Reddy TC, Achari C, Sridhar PR, Reddanna P. Design, synthesis, and biological evaluation of prenylated chalcones as 5-LOX inhibitors. Bioorganic \& Medicinal Chemistry. 2010; 18:5807-5815. [PubMed: 20667741]

157. Sarveswaran S, Myers CE, Ghosh J. MK591, a leukotriene biosynthesis inhibitor, induces apoptosis in prostate cancer cells: synergistic action with LY294002, an inhibitor of phosphatidylinositol 3'-kinase. Cancer Letters. 2010; 291:167-176. [PubMed: 19906484]

158. Fischer AS, Metzner J, Steinbrink SD, Ulrich S, Angioni C, Geisslinger G, et al. 5-Lipoxygenase inhibitors induce potent anti-proliferative and cytotoxic effects in human tumour cells independently of suppression of 5-lipoxygenase activity. British Journal of Pharmacology. 2010; 161:936-949. [PubMed: 20860670]

159. Thun MJ, Namboodiri MM, Heath CW Jr. Aspirin use and reduced risk of fatal colon cancer. The New England Journal of Medicine. 1991; 325:1593-1596. [PubMed: 1669840]

160. Gupta RA, Dubois RN. Colorectal cancer prevention and treatment by inhibition of cyclooxygenase-2. Nature Reviews. Cancer. 2001; 1:11-21.

161. Cha YI, DuBois RN. NSAIDs and cancer prevention: targets downstream of COX-2. Annual Review of Medicine. 2007; 58:239-252.

162. Witton CJ, Hawe SJ, Cooke TG, Bartlett JM. Cyclooxygenase 2 (COX2) expression is associated with poor outcome in ER-negative, but not ER-positive, breast cancer. Histopathology. 2004; 45:47-54. [PubMed: 15228443]

163. FDA warning on NSAID use. FDA Consum. 2005; 39:5.

164. Mukherjee D. Nonsteroidal anti-inflammatory drugs and the heart: what is the danger? Congestive Heart Failure. 2008; 14:75-82. [PubMed: 18401215] 
165. Grosser T, Fries S, FitzGerald GA. Biological basis for the cardiovascular consequences of COX-2 inhibition: therapeutic challenges and opportunities. The Journal of Clinical Investigation. 2006; 116:4-15. [PubMed: 16395396]

166. Zhang MZ, Xu J, Yao B, Yin H, Cai Q, Shrubsole MJ, et al. Inhibition of 11 beta-hydroxysteroid dehydrogenase type II selectively blocks the tumor COX-2 pathway and suppresses colon carcinogenesis in mice and humans. The Journal of Clinical Investigation. 2009; 119:876-885. [PubMed: 19307727]

167. Cerella C, Sobolewski C, Dicato M, Diederich M. Targeting COX-2 expression by natural compounds: a promising alternative strategy to synthetic COX-2 inhibitors for cancer chemoprevention and therapy. Biochemical Pharmacology. 2010; 80:1801-1815. [PubMed: 20615394]

168. Jang M, Pezzuto JM. Cancer chemopreventive activity of resveratrol. Drugs Under Experimental and Clinical Research. 1999; 25:65-77. [PubMed: 10370867]

169. Subbaramaiah K, Chung WJ, Michaluart P, Telang N, Tanabe T, Inoue H, et al. Resveratrol inhibits cyclooxygenase- 2 transcription and activity in phorbol estertreated human mammary epithelial cells. Journal of Biological Chemistry. 1998; 273:21875-21882. [PubMed: 9705326]

170. Kundu JK, Na HK, Chun KS, Kim YK, Lee SJ, Lee SS, et al. Inhibition of phorbol ester-induced COX-2 expression by epigallocatechin gallate in mouse skin and cultured human mammary epithelial cells. Journal of Nutrition. 2003; 133:3805S-3810S. [PubMed: 14608118]

171. Woo ER, Pokharel YR, Yang JW, Lee SY, Kang KW. Inhibition of nuclear factor-kappaB activation by 2',8"-biapigenin. Biological and Pharmaceutical Bulletin. 2006; 29:976-980. [PubMed: 16651730]

172. Corona G, Deiana M, Incani A, Vauzour D, Dessi MA, Spencer JP. Inhibition of p38/CREB phosphorylation and COX-2 expression by olive oil polyphenols underlies their anti-proliferative effects. Biochemical and Biophysical Research Communications. 2007; 362:606-611. [PubMed: 17727817]

173. Barry M, Cahill RA, Roche-Nagle G, Neilan TG, Treumann A, Harmey JH, et al. Neoplasms escape selective COX-2 inhibition in an animal model of breast cancer. Irish Journal of Medical Science. 2009; 178:201-208. [PubMed: 19340516]

174. Ye YN, Wu WK, Shin VY, Bruce IC, Wong BC, Cho CH. Dual inhibition of 5-LOX and COX-2 suppresses colon cancer formation promoted by cigarette smoke. Carcinogenesis. 2005; 26:827834. [PubMed: 15637091]

175. Laufer SA, Augustin J, Dannhardt G, Kiefer W. (6,7-Diaryldihydropyrrolizin-5-yl)acetic acids, a novel class of potent dual inhibitors of both cyclooxygenase and 5-lipoxygenase. Journal of Medicinal Chemistry. 1994; 37:1894-1897. [PubMed: 8021931]

176. Fiorucci S, Meli R, Bucci M, Cirino G. Dual inhibitors of cyclooxygenase and 5-lipoxygenase. A new avenue in anti-inflammatory therapy? Biochemical Pharmacology. 2001; 62:1433-1438. [PubMed: 11728379]

177. Rao PN, Chen QH, Knaus EE. Synthesis and structure-activity relationship studies of 1,3diarylprop-2-yn-1-ones: dual inhibitors of cyclooxygenases and lipoxygenases. Journal of Medicinal Chemistry. 2006; 49:1668-1683. [PubMed: 16509583]

178. Rao P, Knaus EE. Evolution of nonsteroidal antiinflammatory drugs (NSAIDs): cyclooxygenase (COX) inhibition and beyond. Journal of Pharmacy and Pharmaceutical Sciences. 2008; 11:81s110s. [PubMed: 19203472]

179. Rao CV. Regulation of COX and LOX by curcumin. Advances in Experimental Medicine and Biology. 2007; 595:213-226. [PubMed: 17569213]

180. Zhang F, Altorki NK, Mestre JR, Subbaramaiah K, Dannenberg AJ. Curcumin inhibits cyclooxygenase- 2 transcription in bile acid- and phorbol ester-treated human gastrointestinal epithelial cells. Carcinogenesis. 1999; 20:445-451. [PubMed: 10190560]

181. Huang MT, Lysz T, Ferraro T, Abidi TF, Laskin JD, Conney AH. Inhibitory effects of curcumin on in vitro lipoxygenase and cyclooxygenase activities in mouse epidermis. Cancer Research. 1991; 51:813-819. [PubMed: 1899046] 
182. Griesser M, Pistis V, Suzuki T, Tejera N, Pratt DA, Schneider C. Autoxidative and cyclooxygenase- 2 catalyzed transformation of the dietary chemopreventive agent curcumin. Journal of Biological Chemistry. 2011; 286:1114-1124. [PubMed: 21071447]

183. Ohashi Y, Tsuchiya Y, Koizumi K, Sakurai H, Saiki I. Prevention of intrahepatic metastasis by curcumin in an orthotopic implantation model. Oncology. 2003; 65:250-258. [PubMed: 14657599]

184. Bengmark S, Mesa MD, Gil A. Plant-derived health: the effects of turmeric and curcuminoids. Nutrición Hospitalaria. 2009; 24:273-281. [PubMed: 19721899]

185. Zhang B, Wang CL, Zhao WH, Lv M, Wang CY, Zhong WX, et al. Effect of 5-LOX/COX-2 common inhibitor DHDMBF30 on pancreatic cancer cell Capan2. World Journal of Gastroenterology. 2008; 14:2494-2500. [PubMed: 18442195]

186. Bridoux A, Millet R, Pommery J, Pommery N, Henichart JP. Synthesis and biological activity of N-aroyltetrahydro-gamma-carbolines. Bioorganic \& Medicinal Chemistry. 2010; 18:3910-3924. [PubMed: 20451397]

187. Pontiki E, Hadjipavlou-Litina D, Litinas K, Nicolotti O, Carotti A. Design, synthesis and pharmacobiological evaluation of novel acrylic acid derivatives acting as lipoxygenase and cyclooxygenase-1 inhibitors with antioxidant and anti-inflammatory activities. European Journal of Medicinal Chemistry. 2011; 46:191-200. [PubMed: 21106277]

188. Tauler J, Mulshine JL. Combination therapy of PPARgamma ligands and inhibitors of arachidonic acid in lung cancer. PPAR Research. 2008; 2008:750238. [PubMed: 19277204]

189. Hanif R, Pittas A, Feng Y, Koutsos MI, Qiao L, Staiano-Coico L, et al. Effects of nonsteroidal anti-inflammatory drugs on proliferation and on induction of apoptosis in colon cancer cells by a prostaglandin-independent pathway. Biochemical Pharmacology. 1996; 52:237-245. [PubMed: 8694848]

190. Piazza GA, Alberts DS, Hixson LJ, Paranka NS, Li H, Finn T, et al. Sulindac sulfone inhibits azoxymethane-induced colon carcinogenesis in rats without reducing prostaglandin levels. Cancer Research. 1997; 57:2909-2915. [PubMed: 9230200] 


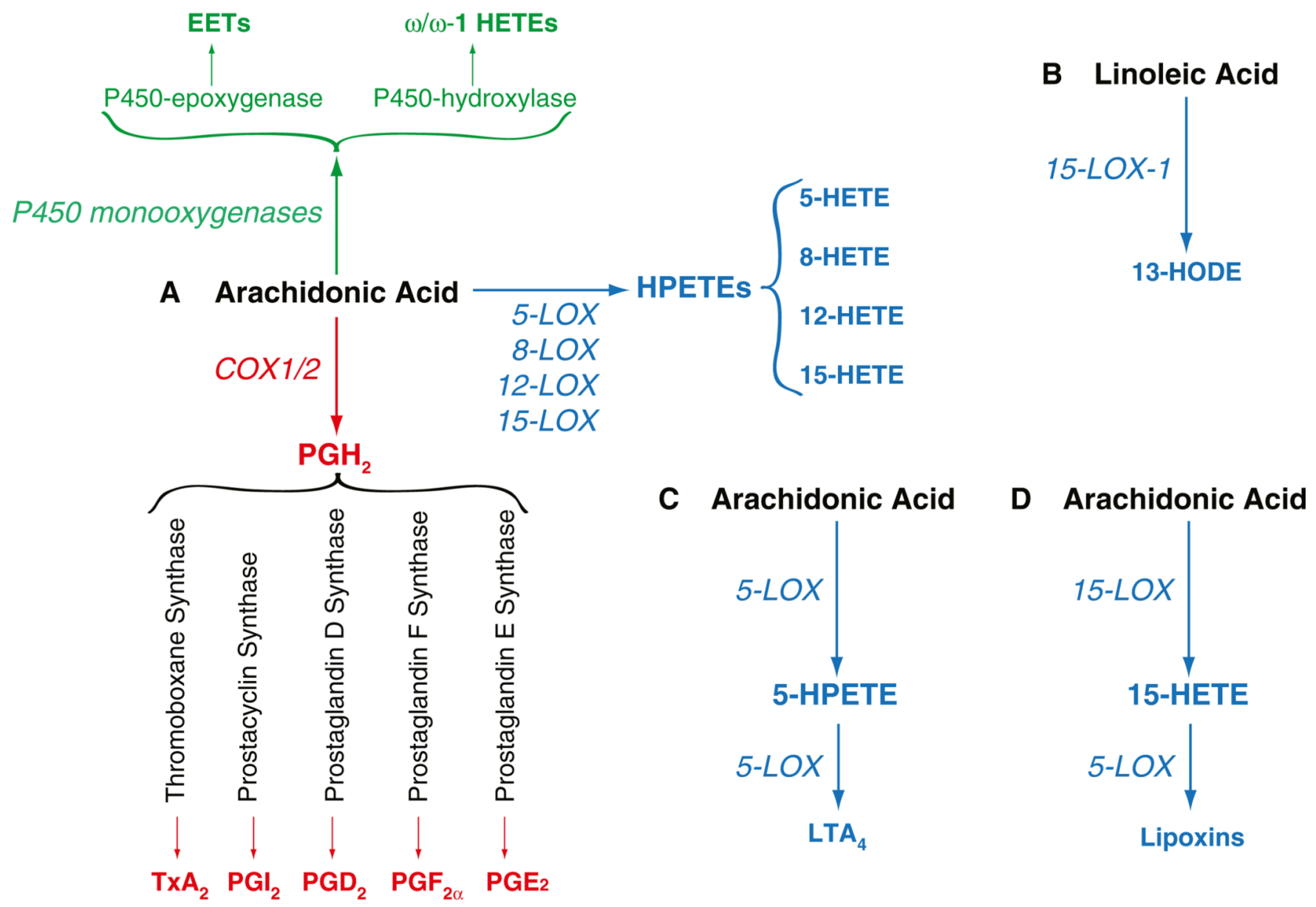

Fig. 1.

Arachidonic- and linoleic-derived products. a Schematic representation of the major arachidonic acid-metabolizing enzymes and their products. Only the contribution of COXand LOX-derived products is discussed in this review. $\mathbf{b}$ Linoleic acid can be metabolized by 15-LOX-1, thus producing 13-HODE. $\mathbf{c}$ In addition to the generation of 5-HETE (a), 5LOX-derived 5-HPETE can be metabolized by 5-LOX to form $\mathrm{LTA}_{4}$. $\mathbf{d}$ Consecutive oxygenation of arachidonic acid by 15-LOX and 5-LOX generates lipoxins 
$\mathrm{PGE}_{2} / \mathrm{EP} 4$

$\mathrm{PGE}_{2} / \mathrm{EP} 3$

$\mathrm{PGE}_{2} / \mathrm{EP} 2$

$P E_{2} / E P 1$

$\mathrm{PGF}_{2 \alpha}$

\author{
$\mathrm{TxA}_{2}$
}

pro-tumorigenic

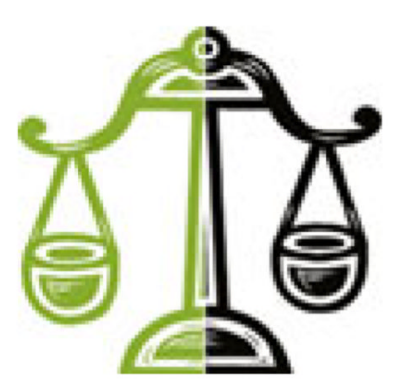

proliferation

survival

migration

invasion

chemokine production

VEGF synthesis

b-FGF synthesis
$\mathrm{PGE}_{2} / \mathrm{EP} 3$

$P E_{2} / E P 1$

$P G D_{2}$

$\mathrm{PGI}_{2}$

\title{
anti-tumorigenic
}

\author{
apoptosis \\ caspase activation \\ Bcl-2 inhibition \\ PPAR activation
}

Fig. 2.

COX-derived eicosanoids in tumorigenesis. Schematic representation of the pro- and antiangiogenic actions mediated by themajor COX products. These lipids can both promote and/ or inhibit tumor growth by acting on tumor cells or the host microenvironment 


\author{
5-LOX \\ 12-LOX \\ 15-LOX-2/15-HETE \\ 15-LOX-1/13-HODE
}

pro-tumorigenic

\author{
8-LOX \\ 15-LOX-2/15-HETE \\ 15-LOX-1/13-HODE \\ 15-LOX/5-LOX/Lipoxins
}

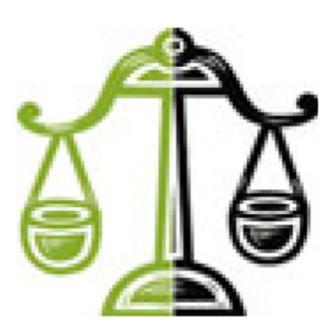

anti-tumorigenic
NF-kB activation

$\mathrm{LTB}_{4}$ synthesis

VEGF synthesis

b-FGF synthesis

Bcl-2 inhibition

G1/S phase transition

mTOR activation

PKC activation

\author{
inhibition of DNA synthesis \\ G0 phase arrest \\ inhibition of pro-angiogenic factors \\ PPAR activation \\ inhibition of focal adhesion \\ inhibition of stress fibers \\ PI3K and ERK inhibition
}

Fig. 3.

LOX-derived eicosanoids in tumorigenesis. Schematic representation of the pro- and antiangiogenic actions mediated by the major LOX products. These lipids can both promote and/or inhibit tumor growth by acting on tumor cells or the host microenvironment 


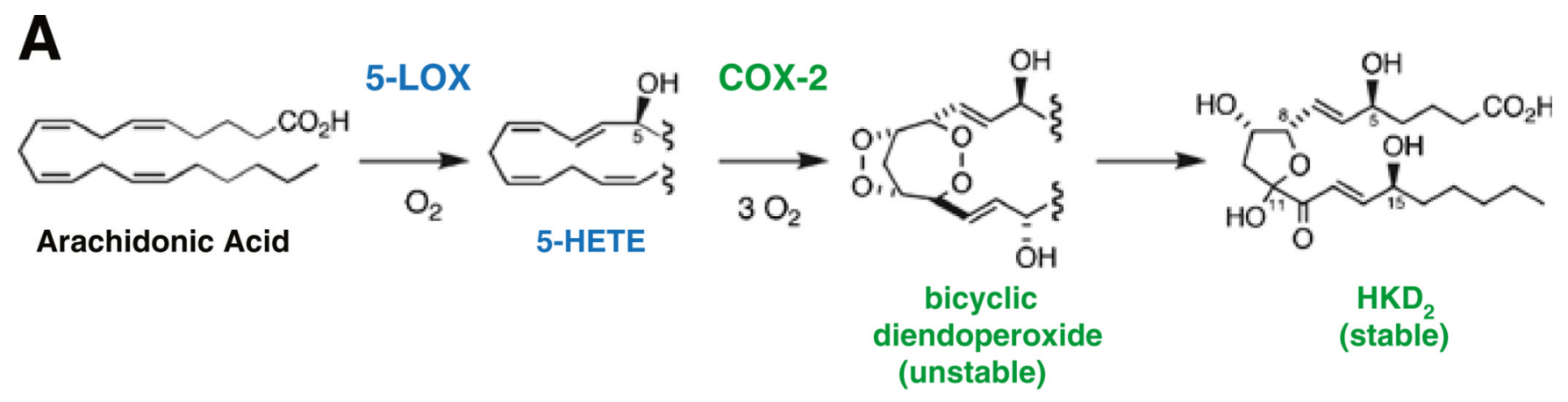

B
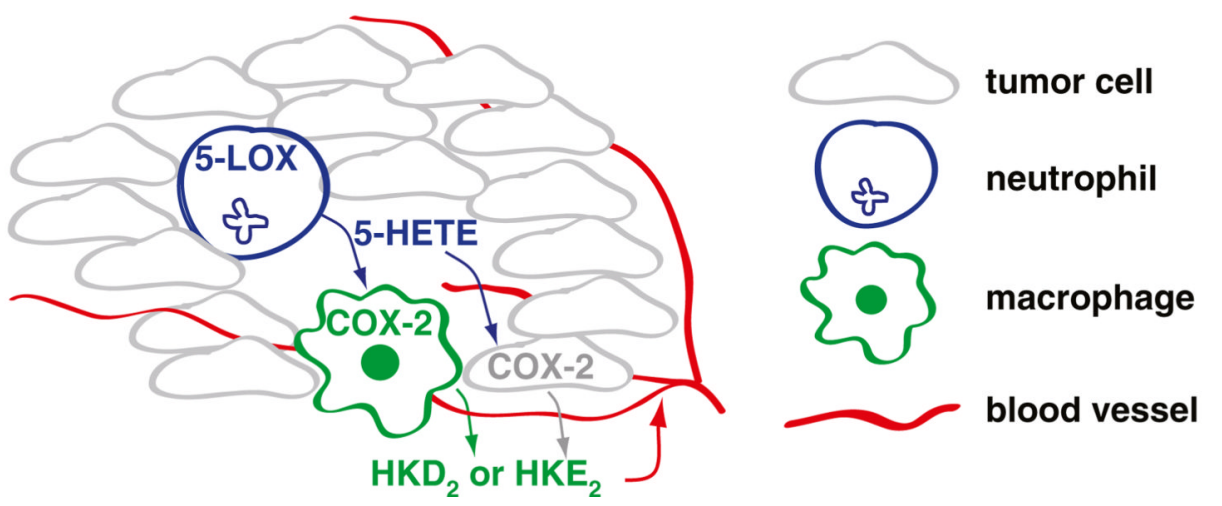

Fig. 4.

LOX-COX-derived eicosanoids in tumorigenesis. a Schematic representation of the generation of cyclic hemiketal (HK) eicosanoids from a converging 5-LOX/COX-2 pathway. Only the generation of $\mathrm{HKD}_{2}$ is illustrated. b Biosynthesis of hemiketals by a tight interaction between neutrophils- macrophages or neutrophils- tumor cells in an inflamed tumor could play a pro-tumorigenic role by stimulating angiogenesis 